\title{
Waste-to-Fuel: A Case Study of Converting Food Waste to Renewable Natural Gas as a Transportation Fuel
}

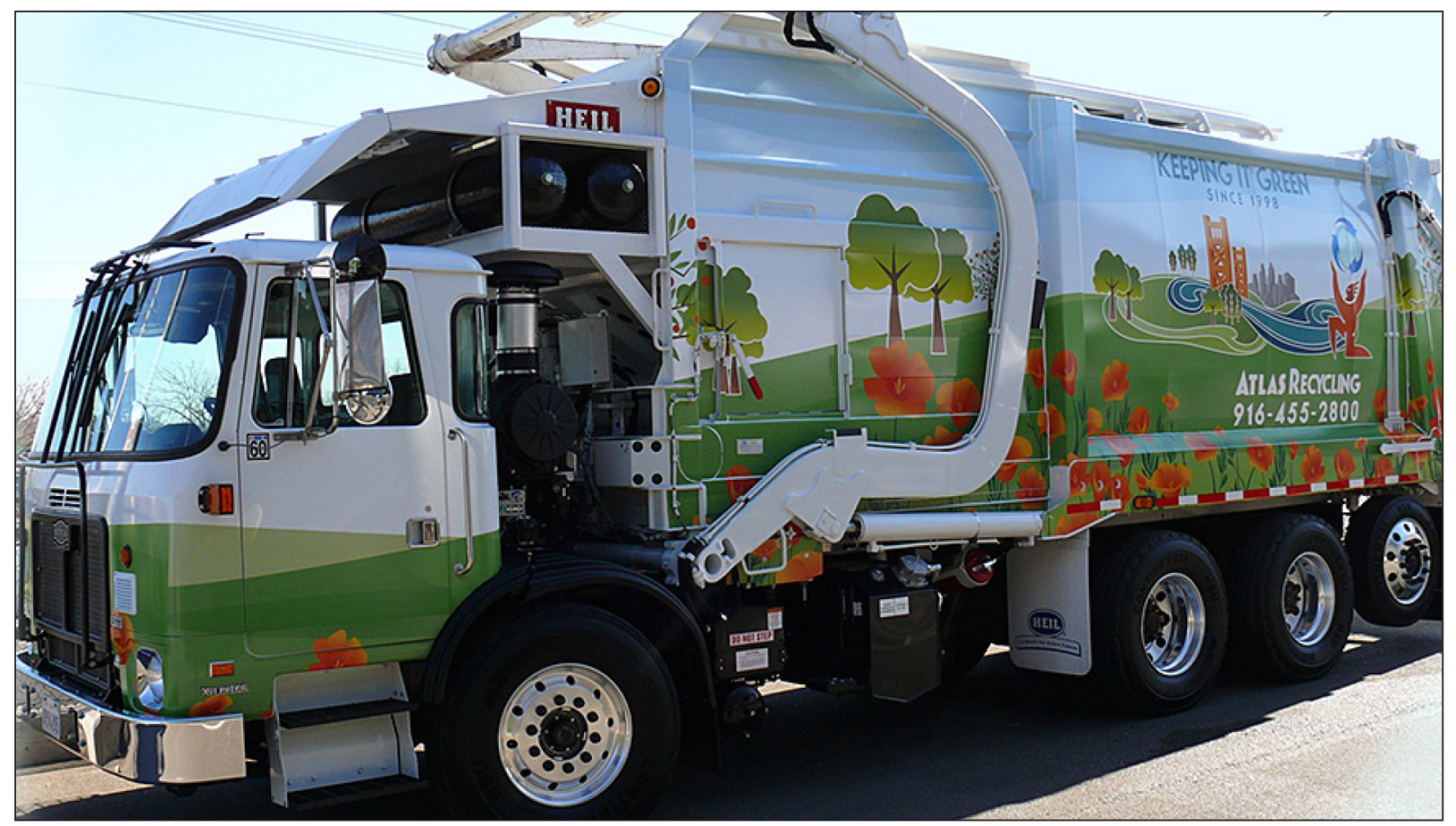

Energy Systems Division 


\section{DOCUMENT AVAILABILITY}

Online Access: U.S. Department of Energy (DOE) reports produced after 1991 and a growing number of pre-1991 documents are available free via DOE's SciTech Connect (http://www.osti.gov/scitech/).

Reports not in digital format may be purchased by the public from the National Technical Information Service (NTIS):

U.S. Department of Commerce

National Technical Information Service

5301 Shawnee Road

Alexandria, VA 22312

www.ntis.gov

Phone: (800) 553-NTIS (6847) or (703) 605-6000

Fax: (703) 605-6900

Email: orders@ntis.gov

Reports not in digital format are available to DOE and DOE contractors from:

U.S. Department of Energy

Office of Scientific and Technical Information

P.O. Box 62

Oak Ridge, TN 37831-0062

\section{Disclaimer}

This report was prepared as an account of work sponsored by an agency of the United States Government. Neither the United States Government nor any agency thereof, nor UChicago Argonne, LLC, nor any of their employees or officers, makes any warranty, express or implied, or assumes any legal liability or responsibility for the accuracy, completeness, or usefulness of any information, apparatus, product, or process disclosed, or represents that its use would not infringe privately owned rights. Reference herein to any specific commercial product, process, or service by trade name, trademark, manufacturer, or otherwise, does not necessarily constitute or imply its endorsement, recommendation, or favoring by the United States Government or any agency thereof. The views and opinions of document authors expressed herein do not necessarily state or reflect those of the United States Covernment or any agency thereof, Argonne National Laboratory, or UChicago Argonne, LLC. 


\section{Waste-to-Fuel: A Case Study of Converting Food Waste to Renewable Natural Gas as a Transportation Fuel}

by

Matthew Tomich

Energy Vision

Marianne Mintz

Energy Systems Division, Argonne National Laboratory

August 2017 



\section{CONTENTS}

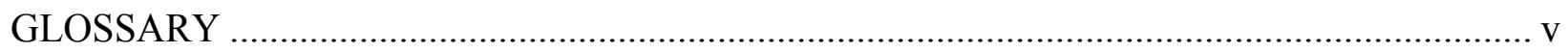

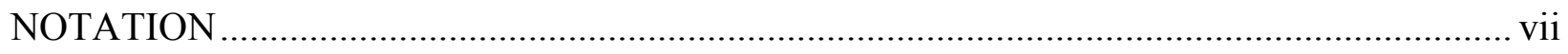

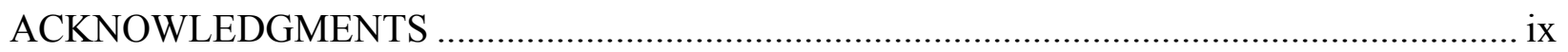

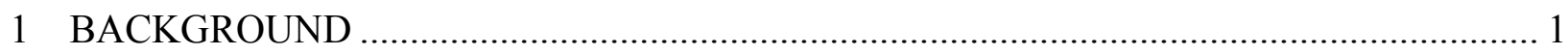

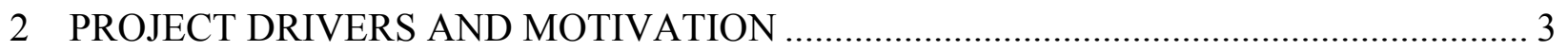

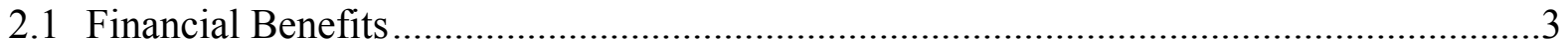

2.2 Existing Natural Gas Vehicles and Infrastructure …………..........................................

2.3 Health and Environment, Energy Security, and Climate Benefits ....................................

2.4 Regulatory and Policy Drivers .....................................................................................

2.4.1 Federal Incentives ......................................................................................

2.4.2 State Incentives ………………………………........................................6

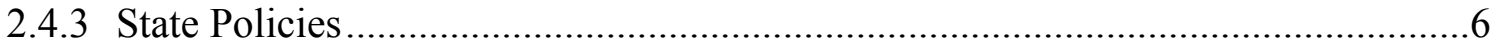

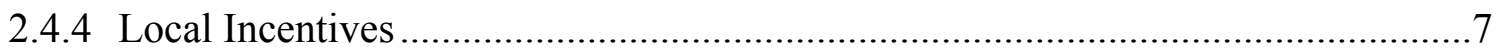

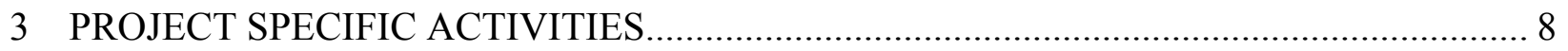

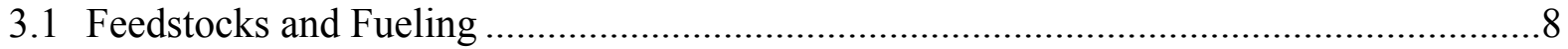

3.2 Technologies and Infrastructure Utilized/Deployed ...................................................

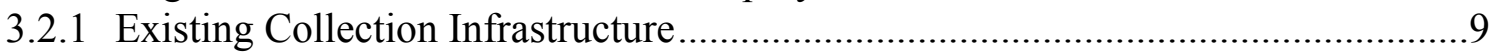

3.2.2 Anaerobic Digestion Technology .....................................................................10

3.2.3 Biogas Upgrading Technology .......................................................................11

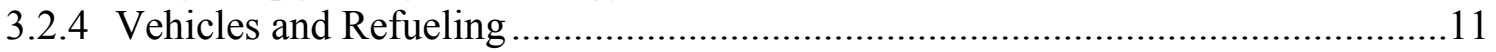

3.3 Public and Private Partnerships ......................................................................................

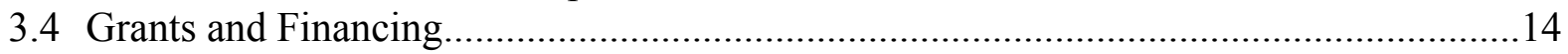

3.5 Anticipated Returns, Operating Costs, and Other Financial Metrics ...............................15

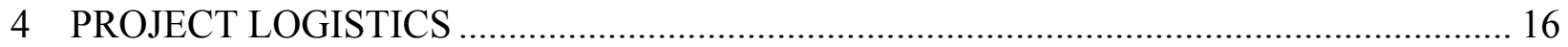

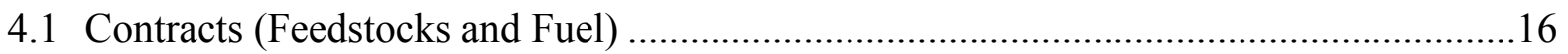

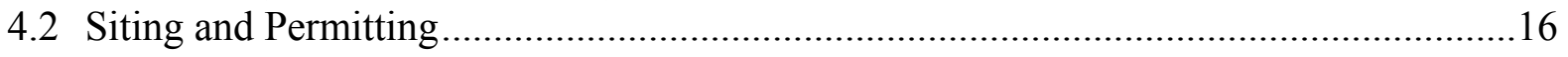

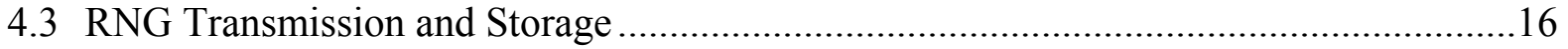

4.4 Monetizing Environmental Attributes........................................................................17

4.5 Project Hurdles .....................................................................................................19

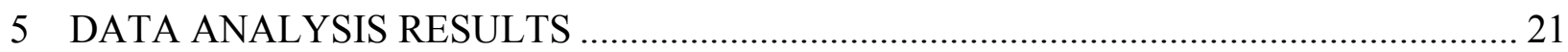

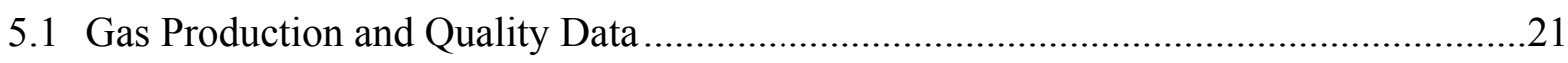

5.2 Environment, Health, and Energy Security Impact Data ................................................2

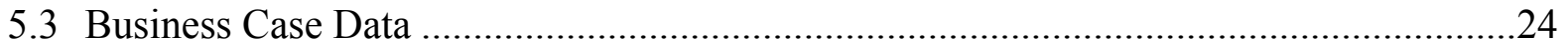

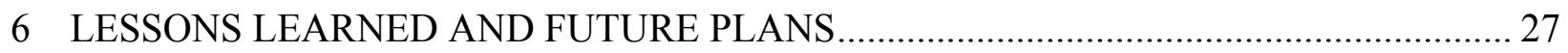

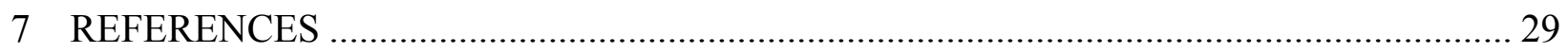




\section{FIGURES}

1 An Atlas Disposal CNG Powered Refuse Truck................................................................ 1

2 The Basic Business Cycle for the Sacramento BioDigester...............................................2

3 Aerial View of the Sacramento BioDigester. ............................................................... 10

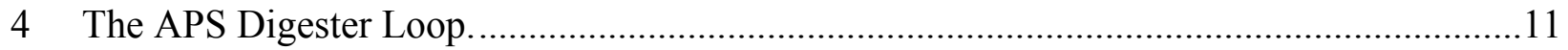

5 A View of the Site from the Refueling Station..............................................................12

6 Relative Refuse Truck Costs, Diesel vs CNG. .............................................................. 12

7 BioDigester Project Financing including 2013 Expansion.............................................14

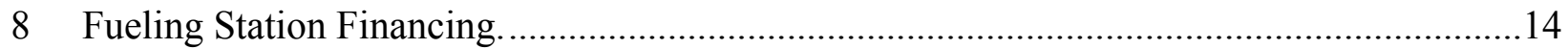

9 RNG Potential of Various Organic Waste Feedstocks. ..................................................21

10 Lifecycle Carbon Intensity of Various Fuels based on California GREET 2.0

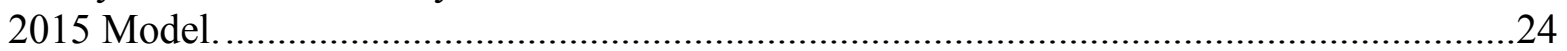

\section{TABLES}

1 CleanWorld Income Projections Based on Low Digestate Sales ........................................15

2 Sample RNG Commodity plus Environmental Credit Values .........................................18

3 Revenue Projections for CleanWorld: 60\% Capacity, 20\% Digestate Sales.......................25

4 Revenue Projections: 60\% Capacity, 100\% Digestate Sales...........................................25

5 Revenue Projections: 100\% Capacity, 20\% Digestate Sales..............................................25

6 Revenue Projections: 100\% Capacity, 100\% Digestate Sales............................................26 


\section{GLOSSARY}

Anaerobic Digestion A process employing heat and beneficial bacteria in an oxygen-free environment to break down organic materials and produce a methane-rich gas mixture (biogas), which can be purified to produce a renewable form of natural gas (RNG).

Digestate The material remaining after the anaerobic digestion process produces biogas. Digestate may be liquid or solid.

Feedstock The base material from which a fuel is produced. Feedstock for renewable natural gas typically includes animal manure, sludge from wastewater treatment plants, food or yard waste, and the organic fraction of municipal solid waste.

GREET The Greenhouse gases, Regulated Emissions, and Energy use in Transportation Model (available at https://greet.es.anl.gov/) calculates energy use, greenhouse gas emissions, and air pollutant emissions associated with over 100 different vehicle and fuel pathways.

Renewable Fuel Standard (RFS/RFS2) The RFS/RFS2, required by the Energy Independence and Security Act of 2007, ensures that transportation fuel sold in the United States contains a certain volume of renewable fuel. RFS2 is an expansion of the initial RFS. It stipulates minimum volumes of specific types of renewable fuels that must be produced each year and combined with conventional motor fuels. Parties obligated to adhere to the RFS/RFS2 - refiners, blenders, or importers - may produce those fuels or purchase the legal right to them. More information is available at https://www.epa.gov/renewable-fuel-standard-program/renewable-fuel-standardrfs2-final-rule.

Renewable Identification Number (RIN) RINs are the "currency" of the RFS2 program; RIN credits are used to demonstrate compliance. A unique number is associated with each unit of fuel qualified under the RFS2 program. RINs can be sold to obligated parties to satisfy the requirement that the parties include a minimum renewable content in the fuel they produce, blend, or import. More information is available at https://www.epa.gov/renewable-fuel-standardprogram/renewable-identification-numbers-rins-under-renewable-fuel-standard.

Tipping fee A charge levied per ton of waste delivered by waste haulers to an anaerobic digestion facility. Also called a gate fee. 
This page intentionally left blank. 


\section{NOTATION}

\begin{tabular}{|c|c|}
\hline $\begin{array}{l}\mathrm{AB} \\
\mathrm{AD} \\
\mathrm{APS}\end{array}$ & $\begin{array}{l}\text { Assembly Bill } \\
\text { anaerobic digester/digestion } \\
\text { Anaerobic Phased Solids }\end{array}$ \\
\hline Btu & British thermal unit(s) \\
\hline CalRecycle & California Department of Resources Recycling and Recovery \\
\hline CA GREET & $\begin{array}{l}\text { California modified Greenhouse Gases, Regulated Emissions, and Energy Use } \\
\text { in Transportation model }\end{array}$ \\
\hline CARB & California Air Resources Board \\
\hline CEC & California Energy Commission \\
\hline CNG & Compressed Natural Gas \\
\hline $\mathrm{CO}$ & carbon monoxide \\
\hline $\mathrm{CO}_{2}$ & carbon dioxide \\
\hline Cu. yd(s) & cubic yard(s) \\
\hline DGE & diesel gallon equivalent \\
\hline (U.S.) DOE & (United States) Department of Energy \\
\hline (U.S.) EPA & (United States) Environmental Protection Agency \\
\hline (U.S.) EIA & (United States) Energy Information Administration \\
\hline FEL & front end load \\
\hline FOG & fats, oils and grease \\
\hline GGE & gasoline gallon equivalent \\
\hline GHG & greenhouse gas \\
\hline GRAS & Green Restaurant Alliance of Sacramento \\
\hline GREET & Greenhouse Gases, Regulated Emissions, and Energy in Transportation model \\
\hline LCFS & Low Carbon Fuel Standard \\
\hline MJ & megajoule \\
\hline mmBtu & million British thermal units \\
\hline MORe & Mandatory Commercial Organics Recycling \\
\hline NOx & nitrous oxides \\
\hline OEM & original equipment manufacturer \\
\hline PG\&E & Pacific Gas \& Electric \\
\hline $\mathrm{PM}$ & particulate matter \\
\hline psi & pounds per square inch \\
\hline
\end{tabular}




$\begin{array}{ll}\text { R-CNG } & \text { Renewable Compressed Natural Gas } \\ \text { RFP } & \text { Request for Proposals } \\ \text { RFS(2) } & \text { Renewable Fuel Standard } \\ \text { RIN } & \text { Renewable Identification Number } \\ \text { RO } & \text { roll off } \\ \text { RNG } & \text { Renewable Natural Gas } \\ \text { RVO } & \text { Renewable Volume Obligation } \\ \text { SATS } & \text { South Area Transfer Station } \\ \text { SBD } & \text { Sacramento BioDigester } \\ \text { SMUD } & \text { Sacramento Municipal Utility District } \\ \text { SOx } & \text { sulfur oxides } \\ \text { tpd } & \end{array}$




\section{ACKNOWLEDGMENTS}

\section{REVIEWERS}

Linda Bluestein, U.S. DOE Clean Cities Program

Sean Moen, Atlas ReFuel

Marcy Rood, Argonne National Laboratory

\section{SPONSOR}

This case study was sponsored by the U.S. Department of Energy's Clean Cities Program. 
This page intentionally left blank. 


\section{BACKGROUND}

This case study explores the production and use of renewable compressed natural gas (R-CNG) - derived from the anaerobic digestion (AD) of organic waste - to fuel heavy-duty refuse trucks and other natural gas vehicles in Sacramento, California. Like fossil compressed natural gas (CNG), waste-derived renewable CNG enables fleets to save on fuel costs, operate more quietly, and emit fewer greenhouse gases (GHG) and pollutants (see Figure 1). In addition, by diverting organic waste from landfills and capturing the biogas that would have been emitted as the waste

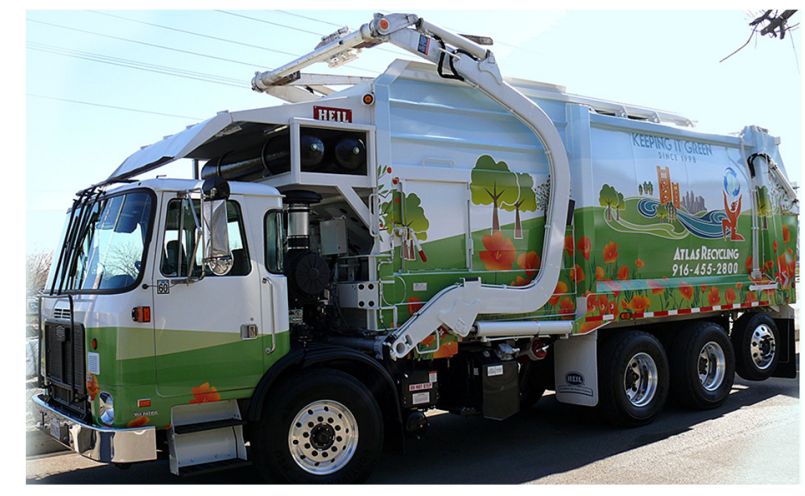

FIGURE 1 An Atlas Disposal CNG Powered Refuse Truck. (Photo courtesy of Matt Tomich.) breaks down, production of R-CNG eliminates potent methane emissions that would otherwise escape into the atmosphere, achieving significant GHG reductions above and beyond fossil CNG.

This case study highlights Atlas Disposal Industries, a waste management and recycling services company; CleanWorld, a technology provider specializing in anaerobic digesters; and their joint endeavor to create a closed-loop organic waste-to-vehicle fuel project in Sacramento, California.

In May 2011, Sacramento County issued a request for proposals (RFP) to re-develop, specifically via public-private partnership, a then "underutilized public asset"- the South Area Transfer Station (SATS) - into a facility that would "produce green energy and/or fuel from residential and/or commercial solid waste or from organic wastes such as green waste or food waste." CleanWorld Partners, a Sacramento clean technology startup, contacted Atlas Disposal, a Sacramento-region waste company, about submitting a joint response to the RFP. Atlas would become the lead respondent on the joint proposal. ${ }^{2}$

CleanWorld looked to Atlas as a partner specifically because the waste company's 4,000-plus commercial customers ${ }^{3}$ included local restaurants already separating their food waste - the primary feedstock for anaerobic digestion - for a composting program led by the local non-profit Green Restaurant Alliance of Sacramento (GRAS).

The Atlas-CleanWorld joint RFP response proposed transforming the SATS into an organics conversion site, where commercial organic waste would be turned into ultra-lowcarbon R-CNG through the construction of an anaerobic digester; a biogas upgrading system; and a fast-fill CNG fueling station. While Sacramento County had the option of awarding the South Area Transfer Site in separate plots to multiple entrants, ${ }^{4}$ it granted the entirety of the site to Atlas Disposal and CleanWorld. 
Once the site was awarded and funding was secured (for funding see Section 3.3, "Public and Private Partnerships"), the project was developed in two phases beginning in 2013:

- Phase 1 involved the build-out of the initial anaerobic digestion and biogas upgrading systems (25 tons/day organic waste capacity), and construction of the fast-fill natural gas fueling station.

- Phase 2 expanded the digester tank capacity to allow for processing 100 tons/day of organic waste (40,000 tons/year), making the facility one of the largest commercial highsolids food waste digesters in the United States, and the first to create R-CNG vehicle fuel via anaerobic digestion of food waste.

Access to consistent, secure organic waste feedstocks - as well as reliable, long-term markets for the fuel that is created - are critical to the success of any biogas-to-CNG project. The collaboration between Atlas Disposal and CleanWorld enabled each company to leverage its core competencies - for Atlas, collecting waste and managing a vehicle fleet; for CleanWorld, developing, operating, and maintaining anaerobic digesters. The partnership helped them create a closed-loop system - dubbed "farm-to-fork-to-fuel"-in which waste collected by Atlas (and later other haulers as well) is converted into the fuel that powers the Atlas collection trucks, as well as other public and private natural gas vehicles operating in the region (see Figure 2). In late 2012, Atlas created a separate entity for the fueling station and branded it Atlas ReFuel.

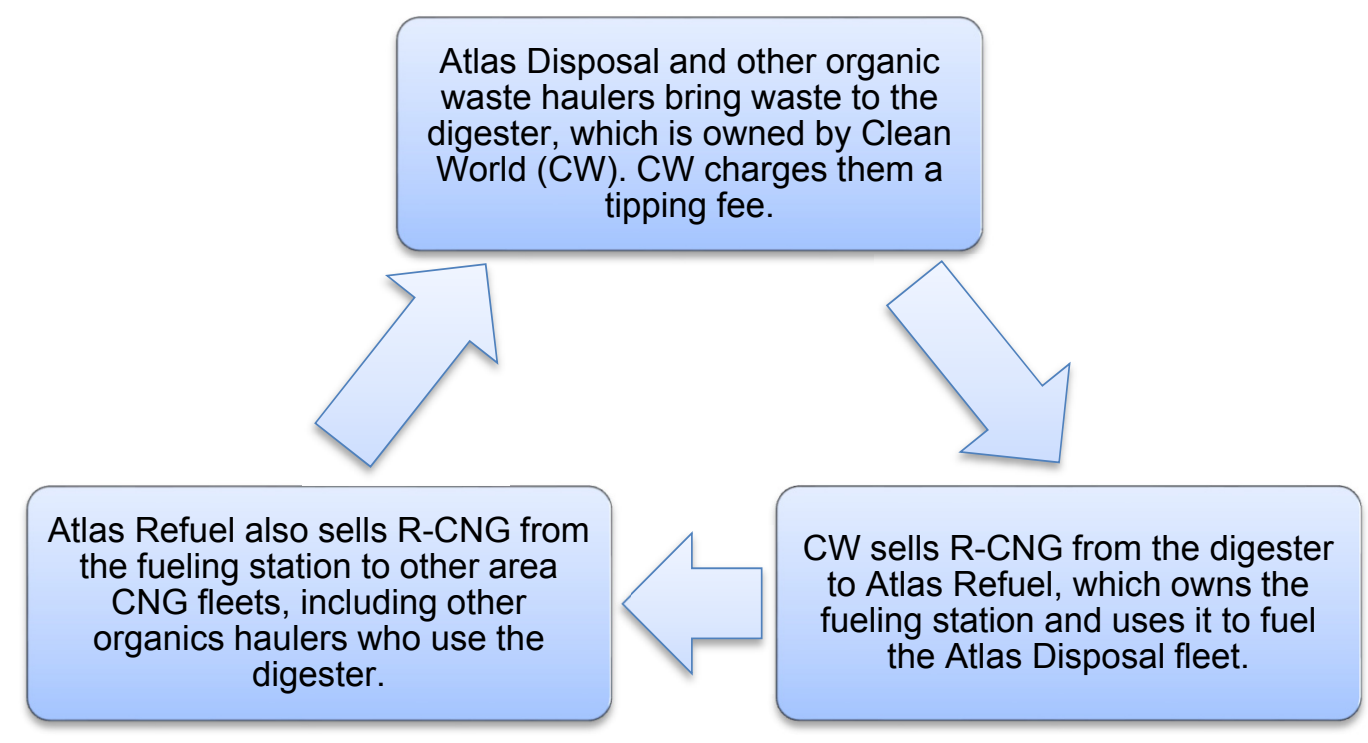

FIGURE 2 The Basic Business Cycle for the Sacramento BioDigester. 


\section{PROJECT DRIVERS AND MOTIVATION}

Commercial and residential food waste diversion mandates at the state level are a relatively recent phenomenon, with requirements coming into effect first in Vermont (2011) and then Massachusetts (2012), Connecticut (2013), and California (2014). Municipal organics recycling programs began in San Francisco (2002). Several others have followed suit, including Seattle (2007), Austin (2011), and New York City (2013). ${ }^{5}$ But there was no such program in place in Sacramento when this project was first conceived.

Atlas Disposal started a boutique organic collection route for customers in 2011-2012, in part due to the success of the GRAS composting program, but also in response to customer requests. ${ }^{6}$ More recently — since the BioDigester began operating - haulers started introducing voluntary, opt-in food waste collection routes for larger customers. The Sacramento area's largest waste haulers, Atlas Disposal and Republic and Waste Management, ${ }^{7}$ now offer such services, helping to supply the SATS anaerobic digester facility with necessary feedstocks. Before the introduction of legislative mandates, uptake on these service offerings was driven by organizations participating in the name of social responsibility. However, the Sacramento BioDigester (SBD) now provides a local disposal option at rates competitive with landfill fees, greatly enhancing the business proposition for waste generators.

\subsection{FINANCIAL BENEFITS}

The primary economic drivers for the project are unique to each partner company.

To Atlas. The transition from diesel to natural gas trucks and the development of the R-CNG fueling station at the Sacramento BioDigester ("SBD") site has had multiple financial benefits:

- Through its subsidiary, Atlas ReFuel, Atlas Disposal has access to a fixed-price vehicle fuel (R-CNG), which, over the long term, balances out the greater cost of CNG trucks (see Section 3.2, "Technologies and Infrastructure");

- Ownership of the fueling station has allowed Atlas Refuel to recruit additional CNG fleet customers, generating more fuel-sales revenue;

- Proximity of the digester (and fueling station) to Sacramento waste generators reduces Atlas Disposal's waste hauling/transport costs compared to landfilling;

- The pre-mandate “tipping" (dumping) fees Atlas paid to CleanWorld (\$30/ton in the original project proposal $^{8}$ ) were competitive with area landfills. 
To CleanWorld. Financial benefits come in the form of three separate but related revenue streams:

- Tipping (or gate) fees - the charge levied on a given quantity of waste - paid at the digester by Atlas Disposal and other organic waste haulers;

- Sale of R-CNG fuel to Atlas ReFuel, and associated state and federal environmental credits (see Section 2.4, "Regulatory and Policy Drivers"); and

- Sale of the solid and liquid digestate - the material remaining after the anaerobic digestion process - to farms and other agricultural operations (still being developed).

Moreover, the location of the digester in Sacramento allows CleanWorld to attract local/regional organic waste generators and haulers who otherwise would have to dispose of material at more distant landfills or compost facilities.

\subsection{EXISTING NATURAL GAS VEHICLES AND INFRASTRUCTURE}

Production and use of R-CNG as a transportation fuel requires not only a consistent, secure stream of organic waste feedstock(s) but also a reliable — ideally, captive - fleet market for the fuel. The Atlas/CleanWorld collaboration ensures that both requirements are met: Atlas Disposal collects and delivers organic waste to the digester, while also providing a market for Atlas ReFuel in the form of its 28 natural gas powered refuse trucks.

Pre-existing public and private sector conversions to natural gas vehicles in the Sacramento region (city and county) - especially refuse vehicles and fleets - have provided Atlas ReFuel a larger and guaranteed market for its refueling station, beyond its own fleet. Sacramento (city and county) CNG vehicles, as well as others from the private sector, regularly refuel at the public access station. In fact, the demand for natural gas at the fueling station now exceeds the R-CNG production capacity of the CleanWorld digester. To overcome this supply/demand imbalance, the station is directly connected to a nearby natural gas pipeline owned and operated by the large California utility Pacific Gas and Electric (PG\&E). With this connection, Atlas ReFuel ensures that the station is supplied with natural gas (renewable or fossil) and is operational 24/7. The PG\&E connection adds a level of redundancy that ensures access to fuel if the digester is down for maintenance or any other reason.

\subsection{HEALTH AND ENVIRONMENT, ENERGY SECURITY, AND CLIMATE BENEFITS}

Natural gas (fossil and renewable) is among the cleanest burning, commercially viable transportation fuel options that exist today. It is also domestically abundant, greatly reducing geopolitical concerns around energy security or disruptions of foreign supplies. Various estimates indicate that the United States has a 100-year or more supply of fossil natural gas. ${ }^{9}$ Recent data from the Energy Information Administration (EIA) indicate that in 2015 domestic 
dry gas production was equal to about $99 \%$ of U.S. consumption (heat, power, transportation fuel, industrial use, etc.), with most of the remainder coming by pipeline from Canada. ${ }^{10}$

Without filters or other emission control systems, natural gas vehicles emit far fewer air pollutants (such as particulate matter [PM], nitrous oxides [NOx], sulfur oxides [SOx], and carbon monoxide [CO]) that are linked to negative environmental and health impacts than petroleum-based fuels. The introduction in 2016 of a new "near zero" emission natural gas engine by Cummins Westport has further enhanced the health benefits of the fuel (fossil or renewable). Approved by the U.S. Environmental Protection Agency (EPA) and California Air Resources Board (CARB), the new engine emits $90 \%$ less NOx or PM than required by even the most stringent standards, making it the cleanest heavy-duty internal combustion engine ever. ${ }^{11}$

Production and use of fossil natural gas in transportation represents a $16 \%$ reduction in climate changing greenhouse gas (GHG) emissions compared to conventional diesel. ${ }^{12}$ But by capturing the biogas generated at the SBD facility, CleanWorld prevents the release of GHGs that would otherwise be emitted if these organic wastes were disposed of in landfills, the third largest anthropogenic source of methane emissions in the United States. ${ }^{13}$

According to detailed research and analyses by the CARB, the anaerobic digestion of food and green waste to create renewable $\mathrm{CNG}$ - on a lifecycle basis including production, use,

and avoided emissions - achieves the greatest GHG reductions of any transportation fuel today. ${ }^{14}$ In fact, CARB has concluded that when this fuel is used on-site to power natural gas vehicles, as with the Sacramento BioDigester facility, the entire process is net-carbon-negative, meaning that methane emissions avoided by diverting waste from landfill, plus petroleum displacement (diesel fuel and synthetic fertilizers), outweigh the direct carbon dioxide $\left(\mathrm{CO}_{2}\right)$ emissions generated by the production and use of R-CNG in vehicles. ${ }^{15}$

\subsection{REGULATORY AND POLICY DRIVERS}

The SBD project benefited from certain government policies that helped move it forward, in the form of both financial incentives and compliance requirements. Generally speaking, regulatory and policy drivers related to the production and use of R-CNG for transportation tend to address the (1) feedstock, (2) fuel, and/or (3) vehicle and refueling infrastructure components of a project.

\subsubsection{Federal Incentives}

On the fuel side at the Federal level, the EPA's Renewable Fuel Standard (RFS2) sets a minimum volume for the amount of renewable fuel that must be used in the transportation sector overall, and is the primary policy driver relevant to R-CNG production for use as a vehicle fuel. To incentivize the production of renewable transportation fuels, credits known as Renewable Identification Numbers (RINs) are generated for each unit of renewable fuel produced in an EPA registered facility. RINs are counted towards each producer, distributor, or refiner's annual Renewable Volume Obligation (RVO), or the amount of non-petroleum fuel they are required 
to offset. One RIN is generated for each volume of renewable fuel produced equal to the energy content of one gallon of ethanol (or approximately 76,000 British thermal units [Btus] on an energy content basis). ${ }^{16,17}$ For RNG, a gaseous rather than liquid fuel that is measured in millions of BTUs (mmBtus), approximately 11.7 RINs are generated for each mmBtu produced. $^{18}$

\subsubsection{State Incentives}

For the Sacramento BioDigester, the most relevant policy to emerge on the fuel side has been California's Low Carbon Fuel Standard (LCFS). The LCFS was originally enacted in 2007 under the umbrella of the Global Warming Solutions Act of 2006 (Assembly Bill [AB] 32 ), the state's overarching mechanism for development and implementation of GHG reduction strategies and programs.

The LCFS requires that by 2020, all fuel "providers" (refiners, blenders, producers, and importers $)^{19}$ in California must reduce the overall carbon intensity of their transportation

fuels by at least $\mathbf{1 0 \%}$ compared to a gasoline/diesel baseline. ${ }^{20}$ To facilitate and incentivize the development of non-petroleum low-carbon fuels, registered alternative fuel providers generate credits based on the overall carbon intensity - and associated carbon reductions relative to petroleum — of the fuel they are producing.

In addition to the credit incentive of the LCFS, the California Energy Commission (CEC), through its Alternative and Renewable Fuel and Vehicle Technology Program, has provided technical assistance and over \$7.3 million dollars to the SBD. These funds have gone toward project feasibility assessments, construction of the fueling facility (built by Californiabased Clean Energy Fuels), and the 2013 digester capacity expansion. ${ }^{21,22}$

\subsubsection{State Policies}

On the feedstock side, the Mandatory Commercial Organics Recycling (MORe) mandate (AB 1826) promotes the recycling of organic waste feedstocks. Approved in 2014 and effective April 1, 2016, AB 1826 was not yet introduced when the SBD project started.

Under AB 1826, all businesses that generate more than a set weekly amount of organic waste (food and green waste, landscape and pruning waste, nonhazardous wood waste, and food-soiled paper waste) must recycle it. The threshold of the requirement started at 8 cubic yards (cu. yds.) per week in 2016, fell to $4 \mathrm{cu}$. yds. in 2017, and could drop to as little as 2 cu. yds. in $2020 .^{23}$ The law also requires that on and after January 1, 2016, "local jurisdictions" (counties and cities) ${ }^{24}$ across the state implement organic recycling programs to divert organic waste generated by businesses, as well as by multifamily residential dwellings that consist of five or more units. ${ }^{25}$ 


\subsubsection{Local Incentives}

Both the City and County of Sacramento have been supportive of the project, above and beyond the commitment to provide the land at the South Area Transfer Station (SATS). In 2013, the City signed an agreement to purchase up to 2,500 diesel gallon equivalents (DGE) of CNG per week from the station, with a stipulation that at least $30 \%$ of the fuel be R-CNG produced at the digester (i.e., not fossil CNG sourced from the PG\&E back-up supply). The fuel is used by 25 rear-loading collection trucks and three street sweepers. ${ }^{26}$ 


\section{PROJECT SPECIFIC ACTIVITIES}

\subsection{FEEDSTOCKS AND FUELING}

$\mathrm{R}-\mathrm{CNG}$ is derived from the anaerobic decomposition of solid and liquid organic wastes, commonly referred to in the industry as feedstock(s). Feedstocks are collected from various commercial enterprises including big box stores, airports, supermarkets, restaurants, and food manufacturers and processors. At the Sacramento BioDigester, the primary feedstock comes in the form of organics - either delivered directly by the waste generators or collected by Atlas Disposal, Cal Waste Recycling, Waste Management, Republic Services, or other area haulers servicing local restaurants, supermarkets, food-processing companies, schools, businesses with cafeterias or lunchrooms, and large food producers/distributers. ${ }^{27}$

In the Sacramento area, commercial and residential food waste offer the greatest potential sources of feedstock for the SBD. Commercial food waste-from food processors, grocery stores, large cafeterias, and restaurants - is currently the single largest feedstock component; specifically, it contains discarded packaged food from eight processing companies that cannot be donated to shelters or homes, and liquid waste from soda makers and dairy product processors/distributors.

Processing and transportation costs prevent economic use of green waste and fats, oils, and grease from commercial kitchens (FOG), plus generators of these wastes have other lowercost disposal options such as composting, landfill cover, sale as feedstock to existing biomass electrical power plants, and disposal at some area wastewater treatment plants. Limited animal manure feedstock is available from local stables, zoos, and farming operations where land application is not appropriate. While dairy manure is abundant in the region and works well when mixed in a digester with food waste, transporting it is prohibitively expensive. ${ }^{28}$

As of January 2017, the Sacramento BioDigester was running between $60 \%$ and $100 \%$ capacity depending on the day. In 2016, the SBD processed approximately 24,000 tons of organic waste, producing 225,000 DGEs of R-CNG. ${ }^{29}$ Routine and unscheduled digester maintenance and down time limited the volume of R-CNG produced.

Current feedstocks are almost exclusively from private commercial sources, but several municipalities are in talks with Atlas/CleanWorld to start diverting/delivering organics. Municipal or residential organics diversion will be the major growth opportunity as AB 1826 is implemented and expanded.

For Atlas Disposal, delivering organics to the BioDigester facility is more expensive on a per-ton basis than taking it to landfill. (However, the costs to a customer are close to "net zero" due to the reduction in garbage collection.) At the digester, there is some additional labor cost associated with separating organics from non-digestible items, but this is covered by up-charging deliveries containing such materials. ${ }^{30}$ Mechanical separation, in the form of a Doda Bio

Separator system, ${ }^{31}$ de-packages cans, bottles, cartons and more to remove inorganic material 
from the organics stream, allowing acceptance of a wide range of commercial feedstocks, including organics that are still packaged in various types of metal, plastic, and cardboard.

At the BioDigester, biogas is produced from the feedstock and, using BioCNG, LLC biogas upgrading technology, is then purified to vehicle-grade fuel by removing moisture, carbon dioxide, hydrogen sulfide, and other impurities. ${ }^{32}$ Once refined, the RNG is moved into a lowpressure storage tank. As needed, the RNG is drawn from the tank, compressed, and dispensed at the Atlas ReFuel-owned natural gas fueling station.

While there is no single or universal standard for gas quality, CleanWorld, Atlas ReFuel, and vehicle/engine original equipment manufacturers (OEMs) like Cummins Westport have adopted the SAE J1616 quality standard; the California Department of Agriculture's Division of Measurement Standards is considering doing so as well. ${ }^{33}$ To ensure this standard is met, samples of RNG are taken in a high-pressure chamber and sent to a facility for analysis in Washington State weekly.

During project development, CleanWorld and Atlas explored the possibility of injecting RNG into PG\&E's natural gas pipeline. Injection of RNG to natural gas pipelines is the most common practice for waste-derived RNG across the country, especially where large facilities produce more gas than fleet customers can use. There are currently close to 55 projects producing pipeline-quality RNG in the United States; almost all of them interconnect with a natural gas pipeline. ${ }^{34}$

For the Sacramento BioDigester, however, the costs and requirements quoted by PG\&E - in part a result of California's existing stringent requirements for pipeline injection ${ }^{35}$ were significantly higher than those to compress, store, and dispense the R-CNG on-site. Having a large existing fleet of natural gas vehicles in the region greatly reduced the need to inject the RNG into a pipeline and move it to distant vehicle markets. But any further expansion of the SBD facility would be severely limited by the inability to inject excess gas into PG\&E's network.

\subsection{TECHNOLOGIES AND INFRASTRUCTURE UTILIZED/DEPLOYED}

\subsubsection{Existing Collection Infrastructure}

Historically, very limited food and organic waste collection infrastructure existed in the Sacramento region. ${ }^{36}$ But with the development of the CleanWorld anaerobic digestor (AD) facility in Sacramento; a sister plant at the University of California, Davis (UC Davis); a co-digestion facility at the Sacramento County regional wastewater treatment plant; and composting facilities just outside of Sacramento, regional waste haulers have shown increased interest in the new opportunities to effectively collect and divert organic wastes.

Nearly all food waste destined for the CleanWorld facility is collected and delivered by three commercial haulers-Atlas Disposal, Republic Services, and Waste Management. These 
companies offer voluntary food waste collection programs (at additional cost) for their commercial clients, and do not collect any residential waste (the purview of the Sacramento City and County solid waste departments). The Sacramento Rendering Company (SRC) is another area facility that collects organic and food waste, but much of that is used cooking oil grease, which has a commodity value as an animal feed supplement and for producing biodiesel transportation fuel.

\subsubsection{Anaerobic Digestion Technology}

The Sacramento BioDigester was designed and constructed using CleanWorld's proprietary, thermophilic Anaerobic Phased Solids (APS) digestion system. The technology was developed by Dr. Ruihong Zhang, a UC Davis researcher and professor, and commercialized by CleanWorld ${ }^{37}$ following its successful deployment in a small-scale pilot basis at the UC Davis campus. ${ }^{38}$ Combining the best of batch and continuous processing AD technologies, the APS system was developed to handle a wide range of organic wastes and to maximize biogas production, while minimizing pre-treatment requirements. The technology is compact, energy efficient, readily scalable, and designed around commercially available components (see Figure 3). ${ }^{39,40}$ It can also be configured to produce biohydrogen. ${ }^{41}$

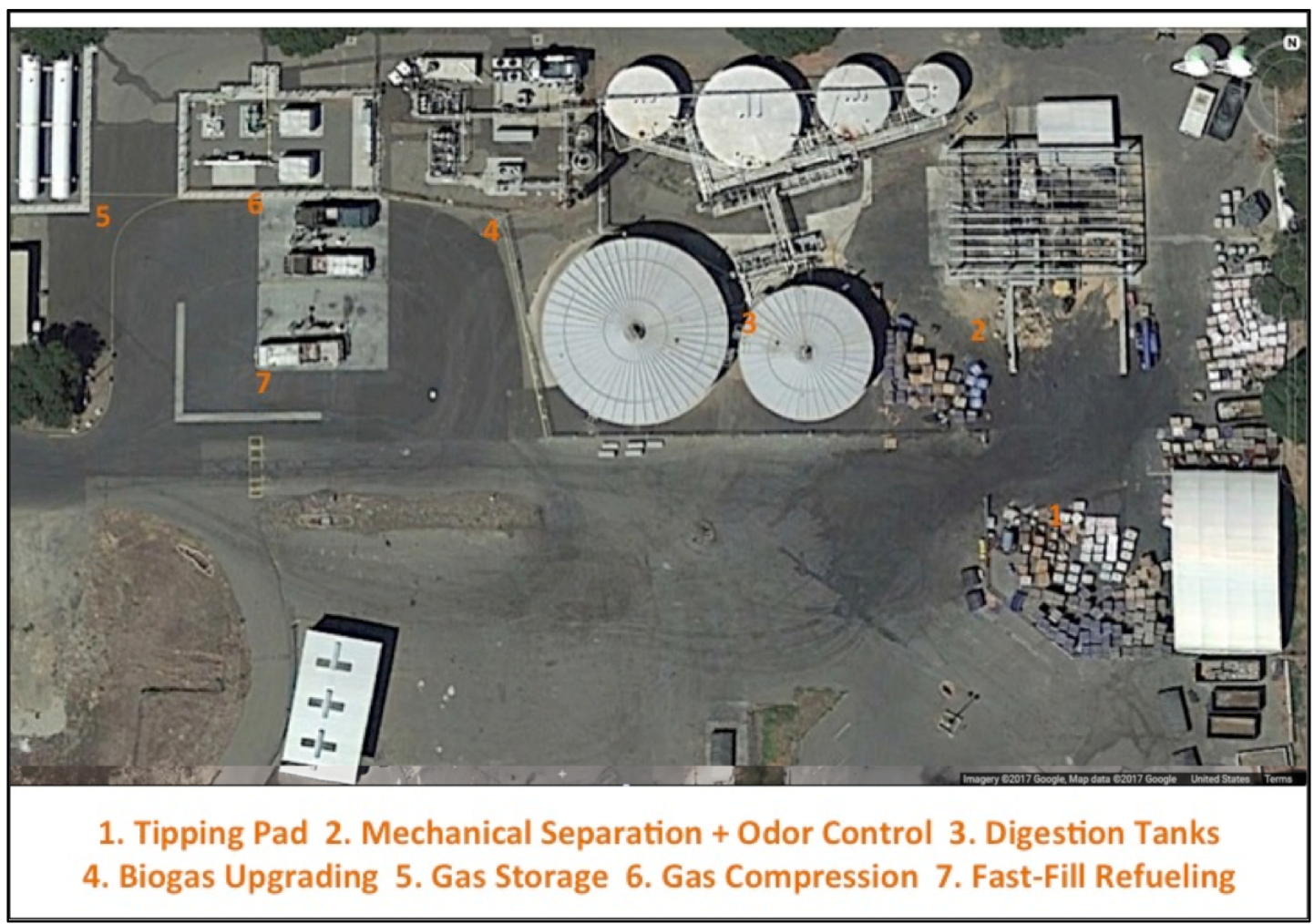

FIGURE 3 Aerial View of the Sacramento BioDigester. (Photo courtesy of Google Earth.) 
The APS digester configuration consists of four hydrolysis reactors and one biogasification reactor. In the hydrolysis reactors, hydrolytic bacteria attack organic materials and break the complex polymers down into simpler monomers, and acidogenic bacteria break down those monomers into volatile fatty acids. The acids are transferred to the bio-gasification reactor, where they are further broken down by methanogenic organisms, yielding biogas. Multiple hydrolysis reactors are batch-fed on different schedules, so each reactor is at a different stage of acidogenesis/volatile fatty acid formation, allowing a stable throughput to the bio-gasification reactor and a constant level of gas production (see Figure 4). ${ }^{42,43}$

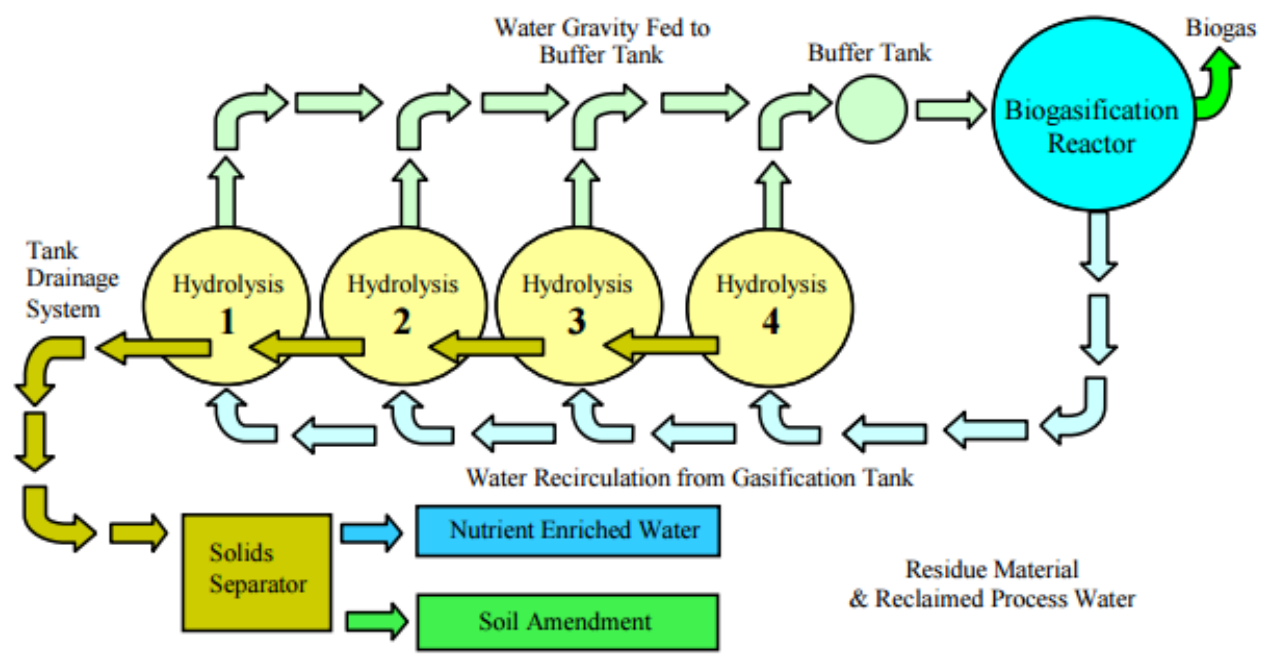

FIGURE 4 The APS Digester Loop. ${ }^{44}$ (Image courtesy of CleanWorld.)

\subsubsection{Biogas Upgrading Technology}

The raw biogas produced during the digestion process is refined using gas separation technology designed and developed for small- and medium-scale biogas sources by BioCNG, LLC, a Wisconsin-based subsidiary of Tetra Tech, Inc. Atlas Disposal and CleanWorld jointly designed the equipment that connects the refined biogas to the fueling station; this includes two 20,000-gallon-equivalent storage tanks used specifically to store gas that exceeds daily dispensing requirements, as may occur on weekends or holidays.

\subsubsection{Vehicles and Refueling}

Atlas Disposal's refuse fleet currently has 28 natural gas trucks that run on R-CNG. These vehicles are Class 8, heavy-duty Front End Load (FEL) and Roll Off (RO) collection vehicles, and use a total of about 250,000 DGEs annually. The trucks were built by Autocar and use Cummins Westport's 8.9-liter ISL G natural gas engines. Atlas plans to purchase only natural gas trucks moving forward, and the company is developing a slow-fill station for its own fleet (see Figure 5). 


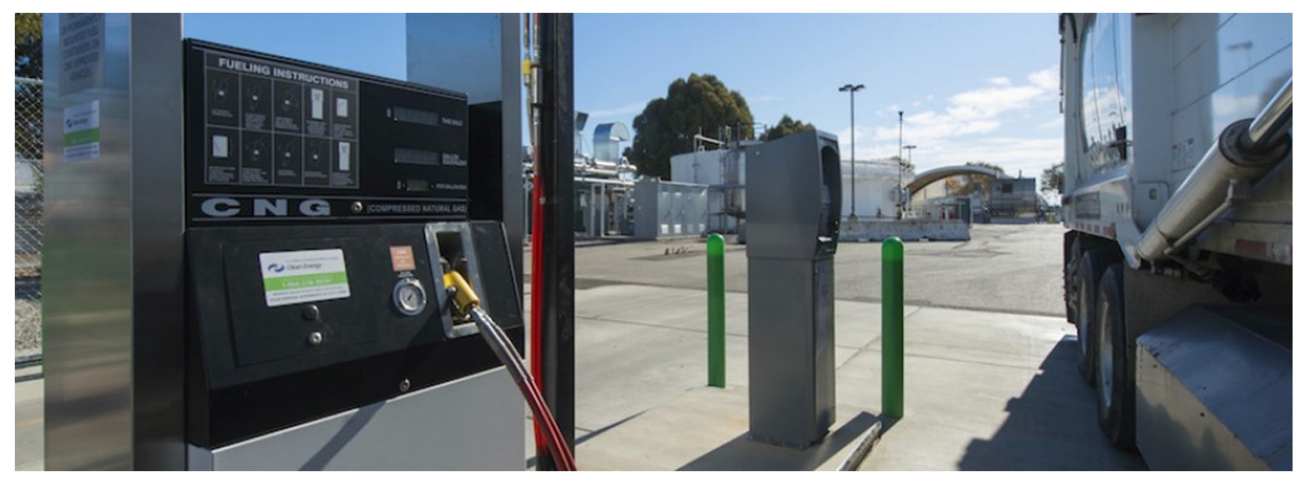

FIGURE 5 A View of the Site from the Refueling Station. (Image courtesy of CleanWorld.)

According to Atlas, CNG-operated refuse vehicles are $\$ 65,000-\$ 75,000$ more expensive than their diesel counterparts, including state and federal excise taxes. A diesel-powered FEL vehicle costs approximately $\$ 325,000$, compared to $\$ 375,000$ for a CNG-powered FEL. Similarly, a diesel-powered RO type vehicle goes for approximately $\$ 190,000$, compared to $\$ 240,000$ for its CNG-powered equivalent. Figure 6 compares diesel and CNG truck costs. Through its supply team and partners, Atlas has secured grant and incentive funding to offset some of the incremental costs. ${ }^{45}$

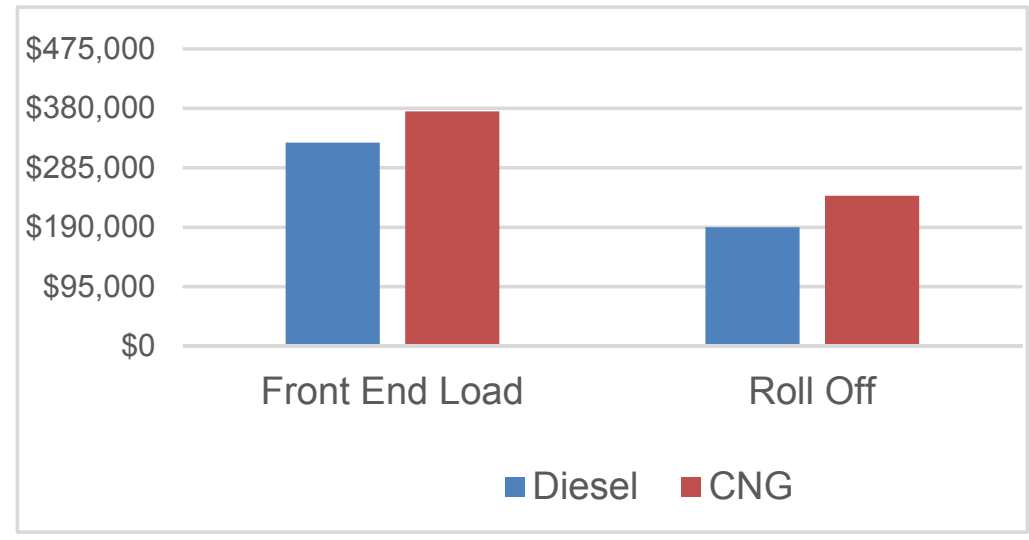

FIGURE 6 Relative Refuse Truck Costs, Diesel vs CNG.

\subsection{PUBLIC AND PRIVATE PARTNERSHIPS}

CleanWorld sells the R-CNG generated by the BioDigester to Atlas ReFuel at a preferred price. From its fueling station (built and maintained by Clean Energy Fuels), Atlas ReFuel sells RNG to the Atlas Disposal fleet, as well as to the general public. Atlas ReFuel has also entered into an agreement with CleanWorld to purchase excess electricity produced at their site by a generator fueled with biogas from the digester (see Section 4.1). ${ }^{46}$ 
The Sacramento BioDigester was conceived as a public-private partnership between CleanWorld and Atlas Disposal on one side and Sacramento County on the other. Funds were provided by Five Star Bank, Central Valley Community Bank, the California Energy Commission, CalRecycle, and Synergex Ventures, the venture capital arm of software firm Synergex..$^{47}$ (Synergex Ventures acquired CleanWorld in January $2011 .{ }^{48}$ )

Otto Construction took on the construction of the facility, ${ }^{49}$ and facility components were fabricated in nearby Yuba County, then assembled in Sacramento County. ${ }^{50}$

Players in the development, oversight, operation, and maintenance of the BioDigester facility include the Carson Development Company, Peabody Engineering, TSS Consultants, Frank M Booth, BioCNG LLC, and Vasko Electric.

Greenwise Joint Venture, a now defunct regional non-profit with a mission to turn Sacramento into a green technology hub, developed a pilot program to facilitate organic waste diversion for businesses and institutions in the Sacramento Region. This program was specifically designed to enhance feedstock delivery to the Sacramento BioDigester, which became a component of the Sacramento area "Farm-to-Fork-to-Fuel" initiative. ${ }^{51}$

The Green Restaurant Alliance of Sacramento (GRAS) is dedicated to making Sacramento a leading sustainable food community, and its members include several restaurants in and around the city. While the Alliance doesn't administer a food or organic waste collection program itself, GRAS assists Sacramento restaurants with food waste diversion concepts and practices, though its emphasis for food waste disposal is on compost. ${ }^{52}$

Since 2014, the Sacramento Metropolitan Air Quality and Management District ("the Air District") has worked with the Sacramento chapter of the non-profit organization BREATHE California on outreach to area schools; this partnership has successfully established food waste recycling programs at seven elementary schools, and is adding new schools to the program on a regular basis. The AmeriCorps program Civic Spark, the Sacramento Municipal Utility District (SMUD) and the Sacramento Solid Waste Authority, along with other agencies and non-profit organizations, are working together in a collaborative called the Biomass Technology Advisory Group to support significant expansion of source separation of food waste in the region, and also to bring food waste recycling to area jails, hospitals, colleges, and cafeteria-equipped office buildings. ${ }^{53}$

The Sacramento Clean Cities Coalition has developed outreach materials and workshops around anaerobic digestion of food waste as a fuel source, sponsored tours of the Sacramento BioDigester, and added AD to the renewable energy technologies featured in the annual Northern California Clean Technology Forum and Equipment Expo. They have also sponsored four AD-centric career training seminars for young adults in area vocational programs. ${ }^{54}$ 


\subsection{GRANTS AND FINANCING}

Overall, the total cost of the completed digester and gas upgrading system (not including the refueling station or any vehicles) was approximately $\$ 13.6$ million; $\$ 6.3$ million of that total - including \$6 million from a CEC grant ${ }^{55}$ - went towards the expansion of the BioDigester that began in the summer of 2013 (Figure 7). ${ }^{56}$

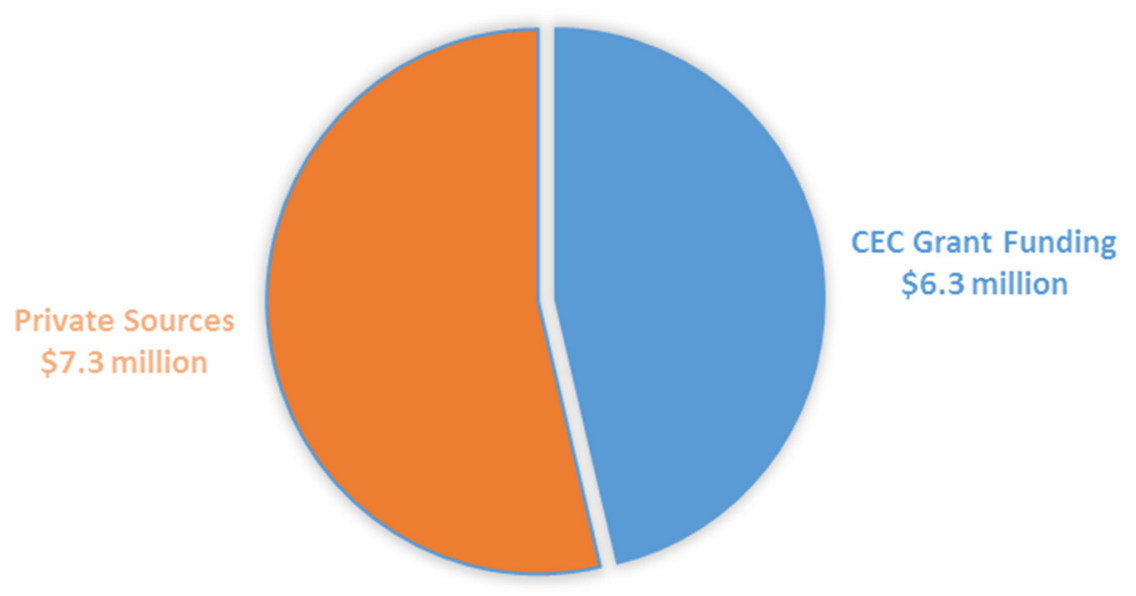

FIGURE 7 BioDigester Project Financing including 2013 Expansion.

The cost of the fueling station totaled \$3.1 million, with Atlas ReFuel covering \$2.8 million, and the remaining $\$ 300,000$ coming from a CEC grant (Figure 8). ${ }^{57}$

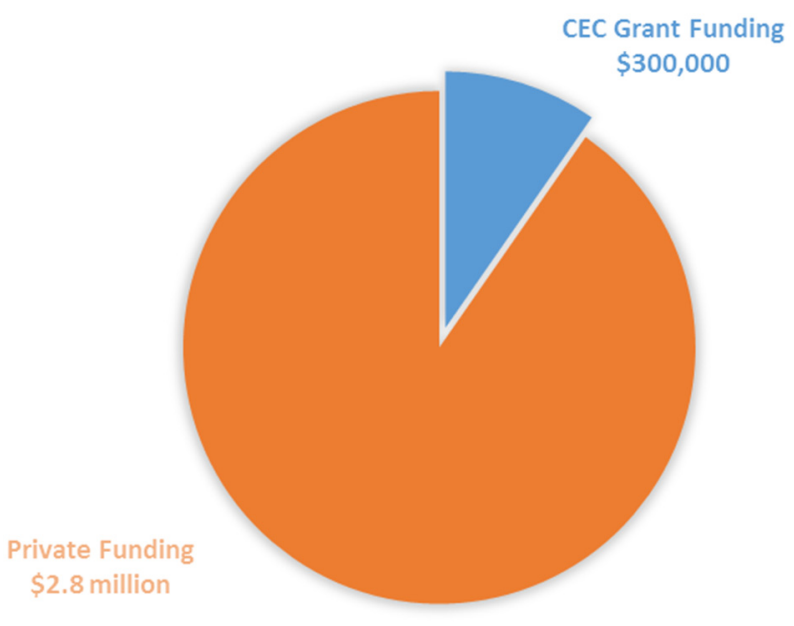

FIGURE 8 Fueling Station Financing. 


\subsection{ANTICIPATED RETURNS, OPERATING COSTS, AND OTHER FINANCIAL METRICS}

The partners anticipated in the original proposal for the SBD that, in Phase 1 of the project, the facility would process 10 tons per day (tpd) of organic waste; in Phase 2, production would scale up to $25 \mathrm{tpd}$, and in successive phases production could reach 100 tpd. ${ }^{58}$ Revenue estimates shown in Table 1 are based on a combination of pricing and projections from that original proposal, supplemented with operational data and assumptions from various other sources. As shown in the table, resulting estimates of anticipated income (tipping fees collected from haulers including Atlas Disposal, sale of biogas to Atlas ReFuel, and sale of compost and fertilizer) are assumed to accrue to CleanWorld. However, because CleanWorld has had limited success monetizing the digester's "back-end" products - the solid and liquid digestate (see Section 4.4, "Monetizing Environmental Attributes"), we assume revenue from those products reaches only $20 \%$ of potential sales.

TABLE 1 CleanWorld Income Projections Based on Low (20\%) Digestate Sales

\begin{tabular}{lrrrr}
\hline \multicolumn{1}{c}{ Item } & & & Subtotal @ 25 tpd, \\
365 days & $\begin{array}{c}\text { Subtotal @ 60 tpd, } \\
\text { 365 days (as of } \\
\text { August 2015) }\end{array}$ \\
\hline Tipping Fees (tons) & Puantity & Price/Unit & & \\
Biogas (GGE/ton) & & $\$ 30.00$ & $\$ 273,750.00$ & $\$ 657,000.00$ \\
Compost (tons) & 17.00 & $\$ 0.63$ & $\$ 97,728.75$ & $\$ 263,143.00$ \\
Liquid Fertilizer (gallons) & 146.50 & $\$ 20.00$ & $\$ 1,825.00$ & $\$ 4,380.00$ \\
Total & & $\$ 0.12$ & $\$ 43,800.00$ & $\$ 105,120.00$ \\
\hline
\end{tabular}

Costs include the digester facility capital cost of $\$ 7.3$ million, not including grant money (see above), and annual operating expenses. The original proposal projected annual expenses of $\$ 150,000$ for a 10 tpd facility. ${ }^{59}$ Valentino Tiangco, of the Sacramento Municipal Utility District, has estimated current operating expenses at $\$ 125,000 .{ }^{60}$ If, for purposes of rough projection, the average of those two values, $\$ 137,500$, is used, the payback time for the facility is estimated to be 11 years under conservative assumptions, e.g., without accounting for environmental attribute value (RIN/LCFS) or up-front grants and incentives. ${ }^{61}$ 


\section{PROJECT LOGISTICS}

\subsection{CONTRACTS (FEEDSTOCKS AND FUEL)}

Atlas ReFuel has an off-take agreement with CleanWorld for low-pressure (10 psi$100 \mathrm{psi}$ ) RNG under an exclusive fuel purchase contract for $100 \%$ of the RNG produced. Fueling station compression for pressure of 3,600 pounds per square inch (psi) is the responsibility of Atlas. Atlas also purchases surplus electricity produced by an on-site, biogas-fueled generator owned and operated by CleanWorld. Under this arrangement, Atlas is the sole "off-taker" of all energy and fuel produced at the facility, which provides certainty and simplifies project logistics. (It also delineates the fuel producer, CleanWorld, from the fuel user(s), a requirement for registering as an EPA-approved facility under the Renewable Fuel Standard.)

In turn, the Sacramento City Unified School District, California State UniversitySacramento, several security companies, and other private entities with natural gas fleet vehicles purchase R-CNG from Atlas ReFuel at the SBD station. On a daily basis, R-CNG is dispensed to $100-150$ vehicles (including refuse trucks, taxis, street sweepers, long-haul trucks, and a variety of delivery vehicles), of which $37 \%$ are from public fleets and $63 \%$ are from private fleets. Because supply from the BioDigester does not meet the total fuel demand at the station, Atlas has an agreement with Clean Energy Renewable Fuels to deliver R-CNG sourced remotely and branded as "REDEEM" to augment the supply.

\subsection{SITING AND PERMITTING}

The land awarded to the Atlas/CleanWorld partnership was for the explicit purpose of a green energy project and was previously permitted as a solid waste transfer station, so no additional air, water, or waste permits were required for its re-purposing. ${ }^{62}$ However, concerns about odor were raised early and often, and were factored into the final project design, which now includes a roof covering the pad where organics are unloaded along with a misting system to prevent foul smells. The relevant California regulatory agencies were engaged and supportive during the entire process. CARB also provided guidance throughout permitting.

\subsection{RNG TRANSMISSION AND STORAGE}

In California, the pipeline injection of landfill-derived renewable natural gas was illegal for almost 30 years. In 2012, California AB 1900 lifted that restriction, but the proceedings that followed left in place the most stringent gas quality standards (and associated expenses) in the country ${ }^{63}$ As a result, there is only one operational pipeline-injection RNG project- the Point Loma Wastewater RNG project developed by BioFuels Energy, LLC, which was built prior to 2012. No new RNG pipeline injection projects are up and running (as of May 2017), but a handful are in development. AB 2773, introduced in early 2016, would have amended the state's prohibitively stringent siloxane requirement in an effort to enable pipeline injection of RNG in a 
state that has significant biogas resources, but as noted, only one operational pipeline injection project exists to date. ${ }^{64,65}$

CleanWorld, which owns the Sacramento BioDigester, is able to circumvent the difficulties of pipeline injection in the state of California by selling the R-CNG produced on-site to Atlas ReFuel, which owns and operates the adjacent CNG fueling station. Gas storage tanks enable the partners to maintain a small back-up supply to allow for continual gas dispensing at the 24/7 refueling station, though vehicles typically only refuel during normal business hours. Atlas' current fueling station has two islands with a total of four fast-fill nozzles, each taking seven minutes to fill a tank completely. All four nozzles can be operated at the same time, but with reduced dispensing rates for each. ${ }^{66}$

As the purified gas exits the upgrading process, it is pressurized to $100 \mathrm{psi}$ by CleanWorld, then sold to Atlas for storing. When a truck starts to fill from the fueling station, it pulls from the R-CNG storage tanks first; once the pressure falls below a certain level, natural gas is pulled from a pipeline running beneath the station. This means that if the BioDigester is down or RNG storage tanks are depleted, the station can dispense natural gas drawn from the local distribution system, providing assurance that vehicles will always have fuel access. Clean Energy Fuels, which offers its REDEEM product to fleet customers from remote sources as discussed above, guarantees that the amount of fossil $\mathrm{CNG}$ drawn from the local gas distribution company is offset by an equivalent amount of RNG introduced to the system elsewhere.

\subsection{MONETIZING ENVIRONMENTAL ATTRIBUTES}

As highlighted in Section 2.4, "Regulatory and Policy Drivers," LCFS credits and Renewable Identification Numbers (RINs) are the primary market mechanisms that encourage or require fuel providers to incorporate renewable and low-carbon fuels into their mix. Since the LCFS is a California state program and the RFS2 is an EPA Federal program, CleanWorld and the Sacramento BioDigester facility are registered under both simultaneously to generate credits for the R-CNG produced and used as transportation fuel. ${ }^{67,68}$

This means that the value of each gallon equivalent of R-CNG is determined by combining the commodity value of fossil natural gas, the value of a RIN credit, and the value of an LCFS credit. The political uncertainty and ongoing legal battles surrounding both the LCFS and RFS2 programs have made credit values highly volatile and difficult to predict. Table 2 provides an example of empirical commodity and credit values based on January 2017 data.

Because the LCFS and RFS2 are designed to incentivize domestic, low-carbon fuel production, it is the fuel producer that generates and owns the credits associated with each program. As the fuel producer, CleanWorld owns these "green gas" environmental attributesthe RINs and LCFS credits - and Atlas owns (after purchase from CleanWorld) the physical commodity, which it then dispenses to its own fleet vehicles or sells to other fleet customers. Typically, the value of these environmental credits is split between the renewable fuel producer (CleanWorld) and fuel distributor (Atlas ReFuel). However, due to confidentiality, the terms of this particular agreement are not publicly available. 


\section{TABLE 2 Sample RNG Commodity plus Environmental Credit Values}

\begin{tabular}{ll}
\hline \multicolumn{1}{c}{ Attribute } & \multicolumn{1}{c}{ Value } \\
\hline & \\
Commodity Gas Value & $\$ 3.00 / \mathrm{mmBtu}$ \\
R-CNG (D5) RIN Value & $\$ 1.00 / \mathrm{RIN}$ \\
RINs/mmBtu & $11.7^{169}$ \\
LCFS Value/GGE & $\$ 1.34($ based on $\$ 95 /$ ton LCFS value $)$ \\
GGEs/mmBTU & 7.8 \\
Total R-CNG Value/mmBtu & $\$ 3.00+(\$ 1.00 * 11.7)+(\$ 1.34 * 7.8)=\$ \mathbf{2 5 . 1 5}$ \\
\hline
\end{tabular}

Qualifying for the LCFS or RFS2 programs requires a thorough registration process designed to prevent fraud. The Sacramento BioDigester facility was registered under the LCFS and has been generating LCFS credits from day one of operation. Registration with the EPA as a qualified producer under the RFS2 was completed with help from an outside consultant; RIN generation began in 2015 after the digester was expanded to handle $100 \mathrm{tpd}$ of commercial organic waste. Under the RFS2, the BioDigester generates LCFS credits under the High Solids Anaerobic Digestion pathway and D5 RINs (biogas from food waste digesters). ${ }^{70}$

In addition to gas sales, associated environmental credits, and the tipping fees charged for disposing organic waste at the facility, the "effluent" that remains in the chamber following anaerobic digestion is also a potential source of revenue. This material, known as "digestate," consists of a liquid and a semi-solid stream, each of which can be turned into a finished product such as fertilizer or soil enhancements.

Following the expansion to 100 tpd, the facility has the capacity to annually produce-in addition to 700,000 DGE of R-CNG and one megawatt (MW) of heat and power used on-site by the digester and the fueling station - eight million gallons per year of soil enhancers and fertilizer products for Sacramento area farms and agriculture. ${ }^{71}$

Liquid digestate from the CleanWorld facility is primarily distributed to a network of local, independent farmers and/or sent to a local wastewater facility for co-digestion. Owing to the high efficiency of CleanWorld's digestion technology, the amount of residual solid digestate that remains is quite small — just four cubic feet per week. Nonetheless, CleanWorld continues to explore on-site finishing/composting as well as higher-value end-use markets for its solid and liquid digestate streams.

In addition to avoided landfill and diesel emissions, the nutrient value and positive environmental impact of these dry and liquid co-products are important factors in the push to divert organics from landfills. ${ }^{72}$ If organics are landfilled, not only is methane emitted to the atmosphere, but these valuable by-products are lost from the nutrient cycle forever. If organics are separately collected and processed — as in Sacramento - the nutrients within these materials

1 Note that RINs are calculated in terms of the higher heating value of ethanol, 84,600 Btu/gallon. Thus, a million Btu of RNG can generate 11.7 RINs. 
can be returned to the soil, reducing the need for petroleum-based synthetic fertilizers. Although the market for these soil co-products has been limited to date, this may change as more organics diversion bans are put in place and anaerobic digester projects are developed.

\subsection{PROJECT HURDLES}

There were no significant setbacks with the fabrication, installation, or operation/maintenance aspects of either the original construction or the expansion process for the digester or fueling station. According to Sean Moen, Atlas ReFuel General Manager, "The ease with which the project came to fruition was largely due to the progressive and supportive nature of Sacramento County and City governments." "73 As discussed, one unforeseen challenge has been the lack of sufficient markets for remaining solid and liquid digestate. CleanWorld is exploring ways to maximize the environmental and economic value of these co-products.

For CleanWorld, the logistics of managing organic feedstock flow was a challenge early on. For example, while much of the organic waste comes to the facility on a scheduled weekly basis, unexpected circumstances among clients - a broken-down refrigerated trailer full of spoiled food or a canceled order at a processor that reduces production for the week - can lead to sudden surges or fall-offs in delivered waste. However, CleanWorld now has systems in place to minimize the effects of feedstock supply variability, including excess digester tank capacity. This means that operations can continue seamlessly whether more or less material than expected is delivered on any given day.

According to Andrea Stephenson at CleanWorld, the Sacramento BioDigester and other first movers in the AD industry face a broader challenge: "As the first and still only approved and permitted AD facility in Sacramento, anytime the CleanWorld plant is down - primarily for routine maintenance - regional haulers are left without an approved facility to properly dispose of the organic materials they collect." While CleanWorld enjoys its distinction as the only operational AD facility in the county, the successful implementation of city, county, or statelevel organics diversion mandates, which are now being rolled out across the country, can be hindered when there is only one operational digester. And until there are other approved facilities/locations, waste generators and haulers alike are completely dependent on CleanWorld as the sole organics recycling option in the region, which can be great for business, but can also pose a challenge if/when the digester is down.

For Atlas Disposal, separate collection of organics necessitated changing collection routes and re-educating customers. Fortunately, this transition was smoother than expected, and significantly increased the amount of organic waste arriving at the BioDigester rather than the landfill. Additionally, Atlas faced challenges with respect to space for containers and service changes based on seasonal needs, such as extra pickups during the hottest summer months (as much as four to five times per week, depending on volumes) to avoid odor issues.

Despite operational and logistical challenges early on, CleanWorld, in partnership with Atlas Disposal and other haulers, continues to secure additional organic waste contracts. While some commercial waste generators have been forward thinking and eager to divert organics to 
the BioDigester, others have been less willing to do so-Atlas Disposal cites lack of education, cost concerns, and space constraints for additional bins as the main deterrents. In addition, providing a clean stream of organic waste feedstock requires constant attention by plant operators to ensure that inorganic materials - such as metal, glass, plastic, or Styrofoam, among others - do not end up in the digester. 


\section{DATA ANALYSIS RESULTS}

\subsection{GAS PRODUCTION AND QUALITY DATA}

Since completion of the 2015 expansion, the Sacramento BioDigester has the capacity to process 36,500 tons of organic waste annually (100 tpd), and produce 705,000 gasoline gallon equivalents ( $1900 \mathrm{GGEs} / \mathrm{day})^{74}$ of R-CNG per year. At peak production, the facility can produce approximately $19 \mathrm{GGEs}$ of RNG per ton of organic waste processed. According to Atlas ReFuel, 560,000 GGEs of R-CNG were dispensed as fuel in 2015, followed by nearly 700,000 GGEs of R-CNG in 2016. The on-site R-CNG production (225,000 GGEs in 2016) was offset by REDEEM sourced and delivered by Clean Energy Fuels.

Gas production and quality varies according to the type of organic waste feedstock. For example, bread and cheese have more energy content than leafy greens or coffee grounds. Figure 9 provides a broad overview of energy value by waste type. The quality and composition of biogas and RNG are monitored weekly to ensure they meet the natural gas engine specifications of Cummins Westport and other engine and vehicle OEMs. Since 2014, the methane content in the raw biogas has fluctuated between $56 \%$ and $62 \%$, with an average of $59.67 \% .^{75}$

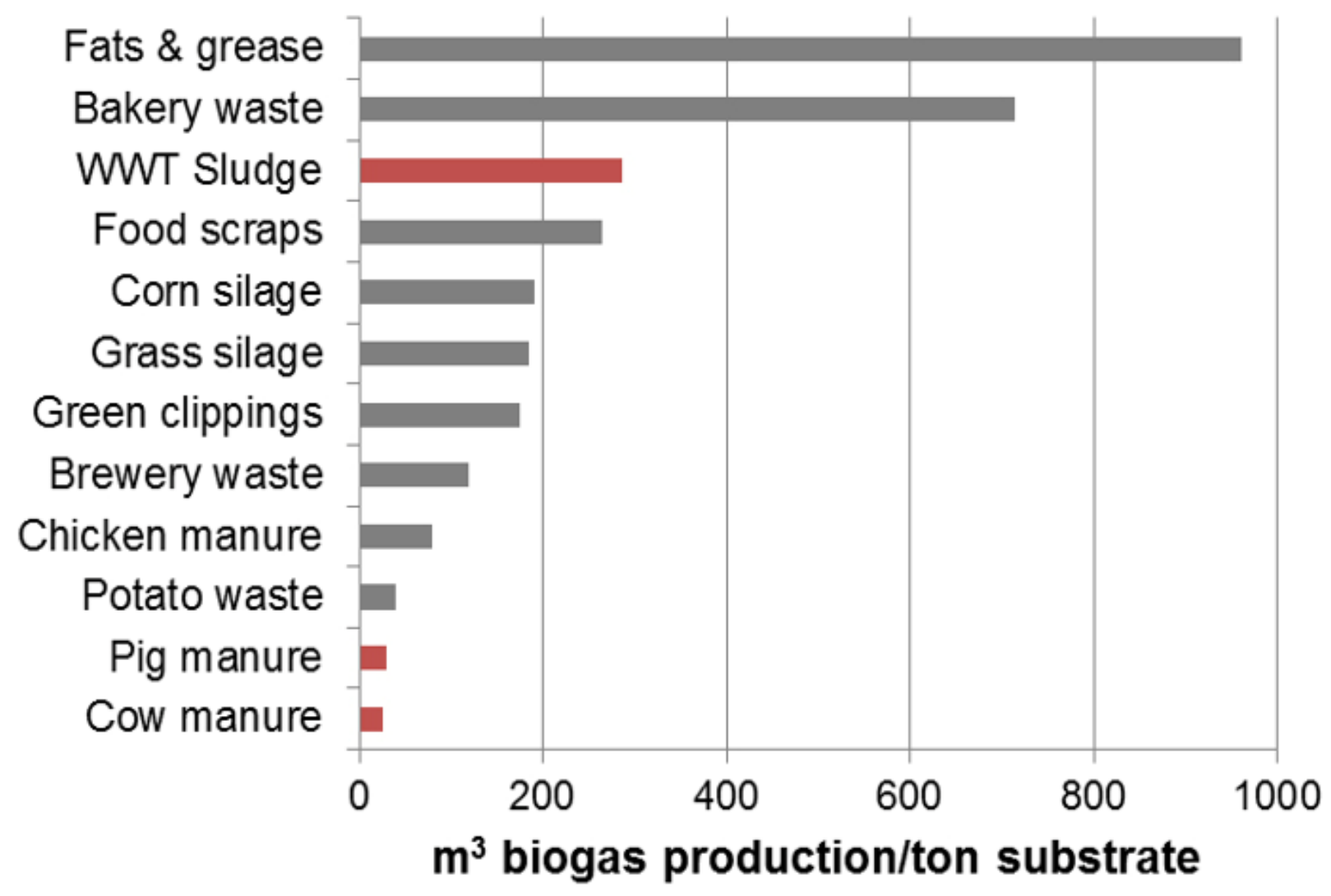

FIGURE 9 RNG Potential ( $\mathrm{m}^{3} /$ ton) of Various Organic Waste Feedstocks. ${ }^{78}$ 
The BioCNG-manufactured upgrading system selected by CleanWorld was developed specifically for the production of transportation-grade RNG from biogas produced at landfills, wastewater facilities, and stand-alone anaerobic digesters. CleanWorld has performed extensive testing, and the gas-upgrading apparatus at the Sacramento site has consistently produced RNG that meets the quality requirements (SAE J1616) for use as transportation fuel. Since 2014, the methane content of this RNG has fluctuated between $96 \%$ and $100 \%$, with an average of $98.3 \%{ }^{76}$ RNG has also been shown to be cleaner than fossil natural gas, in that it lacks heavier hydrocarbon compounds like pentane and ethane that may comprise up to $10 \%$ of fossil gas. ${ }^{77}$

Gas fed into the upgrading system goes through a sequence of cleaning processes: ${ }^{79}$

- Hydrogen sulfide removal. A "passive bed adsorption" method strips hydrogen sulfide $\left(\mathrm{H}_{2} \mathrm{~S}\right)$ from the biogas. Raw biogas passes over a bed of "SULFATREAT," a clay material that has been impregnated with iron oxide; the $\mathrm{H}_{2} \mathrm{~S}$ bonds to the bed material and is left behind. Because this process works best in the presence of moisture, it comes first in the upgrading sequence; the process of drying the gas is next.

- Moisture removal. Removing moisture is an energy intensive and oftenunderappreciated step in biogas purification, and, since natural gas engine specifications for moisture content (again, SAE J1616) in fuel are very strict, the step is also crucial. The Sacramento BioDigester is a high-temperature (thermophilic) system, yielding a relatively "wet" biogas, and moisture is removed in a two-stage cooling process. First the gas passes through a heat exchanger, lowering the temperature to around $40^{\circ} \mathrm{F}$. After the heat exchanger, the gas is chilled (the energy-intensive part) to condense the moisture, which is simply removed by gravity. The heat captured by the heat exchanger is then reintroduced to warm the gas for the next stage in the process.

- Siloxanes and other trace contaminant removal. These contaminants are removed via a passive adsorption system. In this case, the gas passes over activated carbon, and siloxanes and other residuals are left behind. This method is not the most aggressive siloxane removal technology available. However, based on lab testing by CleanWorld, food waste tends to have lower levels of these contaminants than are found in a digester at a wastewater treatment plant, so the passive adsorption is sufficient for the gas produced at the Sacramento facility.

- Carbon dioxide removal. While there are many $\mathrm{CO}_{2}$ removal technologies, compressing the gas and passing it through a molecular sieve was found to be the most cost-effective for the size of the upgrading system required by the Sacramento BioDigester's typical output. Molecular sieves are very efficient at $\mathrm{CO}_{2}$ removal, producing extremely pure RNG at a wide range of flow rates; however, they are less efficient at methane capture. This means that some methane is uncaptured in the upgrading process - at Sacramento, about $25 \%$ to $27 \%$. This "tail gas" is readily combustible in a traditional flare, simplifying emissions control since the same flare used as a fail-safe can also burn the tail gas. The tail gas can also be used to power a generator or micro-turbine. 
In addition to closely monitoring methane content in the biogas, CleanWorld/Atlas also regularly perform the following gas quality tests: ASTM D-1946; ASTM D-5504; and VOC testing per EPA TO-15.

\subsection{ENVIRONMENT, HEALTH, AND ENERGY SECURITY IMPACT DATA}

By diverting and processing organic waste otherwise destined for a landfill, the Sacramento BioDigester achieves a host of environmental, health, and energy security benefits.

1. The production and on-site use of R-CNG annually displaces more than 500,000 gallons of diesel fuel, whose emissions are known to be harmful to human health.

2. The location of the facility and proximity to organic waste feedstocks reduces the distance waste haulers must travel, reducing time, fuel use, and pollution.

3. The diversion of as much as 40,000 tons of organic waste annually eliminates landfill methane emissions.

4. By recovering the nutrients in the digestate, up to eight million gallons of synthetic (petroleum based) fertilizer are eliminated as well. ${ }^{80}$

5. Finally, from an energy security perspective, the Sacramento BioDigester provides a local fuel supply that is impervious to supply disruptions or geopolitics affecting global energy markets.

On a lifecyle emissions basis, accounting for all energy inputs and outputs from fuel production to end-use, R-CNG made from the anaerobic digestion of organic waste at the Sacramento BioDigester is a net-carbon-negative fuel. In other words, the various emissions reductions associated with displacing petroleum (fuel and fertilizer) and avoiding landfill gases exceed the direct emissions generated through the production and use of the fuel.

Detailed analyses performed by the California Air Resources Board conclude that the carbon intensity of R-CNG made from food and green waste is -22.93 grams of $\mathrm{CO}_{2}$ equivalent per megajoule $\left(\mathrm{gCO}_{2} \mathrm{e} / \mathrm{MJ}\right)$, making it the lowest-carbon commercial vehicle fuel that exists today, according to the CA GREET 2.0 model. ${ }^{81}$ Figure 10, from Argonne National Laboratory's national GREET model, shows how this result compares to other fuel pathways and how R-CNG derived from a food waste digester not only meets but exceeds the international goal to reduce global GHG emissions 80\% from 2005 levels by 2050 . 


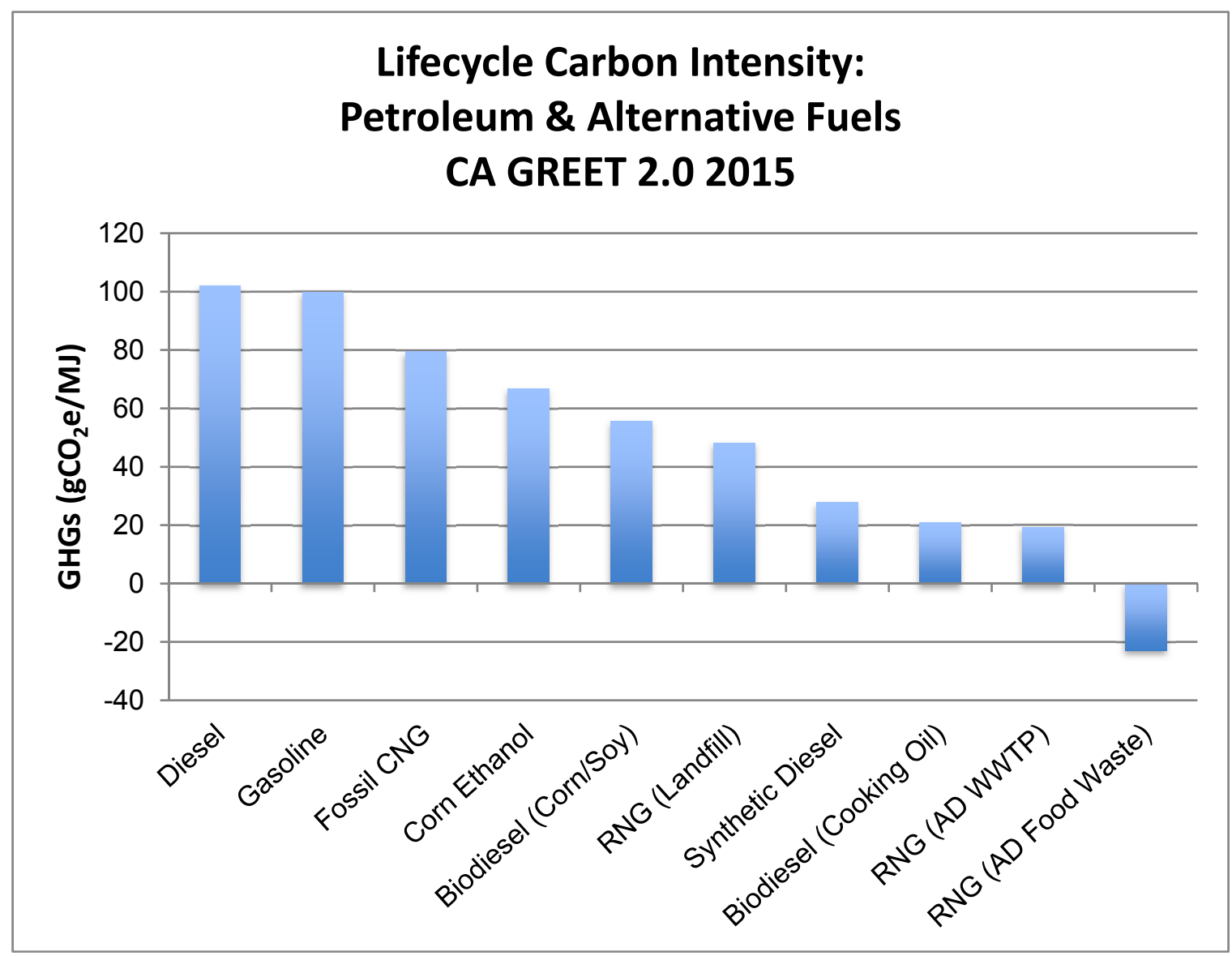

FIGURE 10 Lifecycle Carbon Intensity of Various Fuels (grams $\mathrm{CO}_{2} \mathrm{e} / \mathrm{MJ}$ ) based on California GREET 2.0 2015 Model. ${ }^{82}$

\subsection{BUSINESS CASE DATA}

The Sacramento BioDigester is an example of a successful public-private partnership that has enabled each entity to leverage its resources and expertise. By offering a site for the facility and fueling station, and agreeing to purchase a significant volume of fuel, the county and city of Sacramento helped to facilitate the project without spending tax dollars. The partnership between CleanWorld and Atlas ReFuel enabled them to focus on their core competencies and generate revenue accordingly. Finally, significant grant funding from the CEC cut the capital costs of the project nearly in half, and helped enable project partners to secure private capital to cover the difference.

Thus far, hauling fees represent the greatest single source of revenue for Atlas Disposal; but access to low-cost, fixed-price R-CNG and the ability to mitigate year-to-year fuel price fluctuations have been major cost savings as well. Fuel cost savings, coupled with fuel sales revenue for Atlas ReFuel, have enhanced the company's 2008 commitment to convert its entire refuse fleet to natural gas as older diesel vehicles are retired. 
In the scenarios given in Table 3 through Table 6, tipping fees charged to Atlas Disposal and other haulers make up the majority of project revenue on the CleanWorld side.

TABLE 3 Revenue Projections for CleanWorld: 60\% Capacity, 20\% Digestate Sales

\begin{tabular}{lccc}
\hline \multicolumn{1}{c}{ Item (unit) } & & & $\begin{array}{c}\text { Subtotal @ 60 tpd, } \\
365 \text { days }\end{array}$ \\
& Quantity & Price/Unit & $\begin{array}{c}\text { (as of August 2015) } \\
\text { Tipping fees (tons/day) }\end{array}$ \\
Biogas (DGE/ton) & 60 & $\$ 30.00$ & $\$ 657,000.00$ \\
Compost (tons/year) & 17.00 & $\$ 0.63$ & $\$ 234,549.00$ \\
Liquid fertilizer (gallons/year) & 219.00 & $\$ 20.00$ & $\$ 4,380.00$ \\
TOTAL & $876,000.00$ & $\$ 0.12$ & $\$ 105,120.00$ \\
\hline
\end{tabular}

TABLE 4 Revenue Projections: 60\% Capacity, 100\% Digestate Sales

\begin{tabular}{lccr}
\hline \multicolumn{1}{c}{ Item (unit) } & & & $\begin{array}{c}\text { Subtotal @ 60 tpd, } \\
365 \text { days }\end{array}$ \\
& Quantity & Price/Unit & (as of August 2015) \\
\hline Tipping fees (tons/day) & 60 & $\$ 30.00$ & $\$ 657,000.00$ \\
Biogas (DGE/ton) & 17.00 & $\$ 0.63$ & $\$ 234,549.00$ \\
Compost (tons/year) & 1095.00 & $\$ 20.00$ & $\$ 21,900.00$ \\
Liquid fertilizer (gallons/year) & $4,380,000.00$ & $\$ 0.12$ & $\$ 525,600.00$ \\
TOTAL & - & - & $\$ 1,439,049.00$ \\
\hline
\end{tabular}

TABLE 5 Revenue Projections: 100\% Capacity, 20\% Digestate Sales

\begin{tabular}{lccr}
\hline \multicolumn{1}{c}{ Item (Unit) } & & & $\begin{array}{c}\text { Subtotal @ } 100 \text { tpd, } \\
\text { 365 Days }\end{array}$ \\
\hline & Quantity & Price/Unit & \\
Tipping fees (tons/day) & 100 & $\$ 30.00$ & $\$ 1,095,000.00$ \\
Biogas (DGE/ton) & 17.00 & $\$ 0.63$ & $\$ 390,915.00$ \\
Compost (tons/year) & 365.00 & $\$ 20.00$ & $\$ 7,300.00$ \\
Liquid fertilizer (gallons/year) & $1,460,000.00$ & $\$ 0.12$ & $\$ 175,200.00$ \\
TOTAL & - & - & $\$ 1,668,415.00$ \\
\hline
\end{tabular}


TABLE 6 Revenue Projections: 100\% Capacity, 100\% Digestate Sales ${ }^{83}$

\begin{tabular}{lcrc}
\hline \multicolumn{1}{c}{ Item (Unit) } & & & $\begin{array}{c}\text { Subtotal @ } 100 \text { tpd, } \\
365 \text { days }\end{array}$ \\
\hline Tipping fees (tons/day) & 100 & $\$ 30.00$ & $\$ 1,095,000.00$ \\
Biogas (DGE/ton) & 17.00 & $\$ 0.63$ & $\$ 390,915.00$ \\
Compost (tons/year) & $1,825.00$ & $\$ 20.00$ & $\$ 36,500.00$ \\
Liquid fertilizer (gallons/year) & $7,300,000.00$ & $\$ 0.12$ & $\$ 876,000.00$ \\
TOTAL & - & - & $\$ 2,398,415.00$ \\
\hline
\end{tabular}




\section{LESSONS LEARNED AND FUTURE PLANS}

The Sacramento BioDigester project was the first public-private partnership in the country to turn commercial organic waste into R-CNG vehicle fuel via anaerobic digestion. The facility has been operating successfully-first at $25 \mathrm{tpd}$ and now at $100 \mathrm{tpd}$ - since June of 2013. Because the trucks that collect and haul the commercial organic waste are powered by renewable CNG made from that same organic material, the project is effectively a "closed loop." Since Sacramento is surrounded by one of the largest, most fertile agricultural regions in the world, area leaders have coined the term "farm-to-fork-to-fuel" for the process utilized at the BioDigester facility.

The project relies on three distinct revenue streams: (1) tipping fees; (2) the sale of gas and of associated environmental attributes (credits under Federal and State programs); and (3) the sale of co-products derived from the solid and liquid digestate that is produced.

All of the technologies represented at the Sacramento BioDigester are proven and commercially available; the primary challenges have been in understanding and reacting to the logistical and operational complexities of collecting, handling, and processing organic waste and producing vehicle-grade renewable natural gas.

The environmental, health, and energy security benefits associated with diesel displacement and landfill diversion are significant. Direct and indirect emissions reductions resulting from the production and use of R-CNG (made via anaerobic digestion of food and green waste) as a transportation fuel mean that, on a lifecycle basis, the fuel is net-carbonnegative. Therefore, R-CNG not only meets but exceeds the international goal to reduce global greenhouse gas emissions $80 \%$ from 2005 levels by 2050 .

The diversion and beneficial use of organic waste is a growing trend nationally, driven by its environmental benefits. In fact, in 2014, the U.S. Department of Agriculture, U.S. Department of Energy (DOE), and U.S. Environmental Protection Agency (EPA) collaborated to produce a

"Biogas Roadmap." This report, developed under the White House Climate Action Plan, highlighted the potential to meet a wide range of environmental goals by collecting and processing different types of organic waste to make biogas.

Traditionally, biogas has been used to generate heat or power. However, the development of new and better AD and gas-upgrading technologies, and the expansion of natural gas vehicles and fueling infrastructure, have made biogas-to-CNG an attractive option. Moreover, state and federal policy (LCFS and RFS2) geared toward the production and use of low-carbon, nonpetroleum transportation fuels has greatly incentivized this growing end-use option. Today, waste generators and handlers are increasingly interested in exploring anaerobic digestion facilities to turn organic waste into R-CNG.

The technologies implemented at the Sacramento BioDigester facility are well suited for handling institutional, commercial, and municipal organic waste. The technologies can be easily implemented in other areas producing waste streams of a similar size. Based on the success(es) 
of this project, Atlas Disposal is committed to converting its entire fleet to run on natural gas (fossil or renewable). The company is also planning to expand its organics collection service as California's Mandatory Commercial Organics Recycling (MORe) law takes effect. Similarly, CleanWorld has been exploring additional project opportunities in California and beyond. 


\section{REFERENCES}

1. County of Sacramento, Municipal Services Agency, Department of Waste Management and Recycling, "Request for Qualifications, Public Private Partnership for Energy Conversion Projects at Sacramento County's South Area Transfer Station" (February 7, 2011. Provided by Doug Kobold, Department of Waste Management and Recycling, County of Sacramento, following personal communication.)

2. Atlas Disposal Industries, "Proposal: Public Private Partnership for the Sacramento Biorefinery \#1 Energy Conversion Project at Sacramento County's South Area Transfer Station" (Proposal, July 1, 2011. Provided by Doug Kobold.)

3. Ibid.

4. Ibid.

5. Institute for Local Self Reliance, "Food Scrap Recovery Policies." Accessed November 22, 2016. https://ilsr.org/rule/food-scrap-ban/.

6. Sean Moen, Atlas ReFuel General Manager, personal communication.

7. Valentino Tiangco, Sacramento Municipal Utility District (SMUD) Unpublished report and personal communication, September 2015.

8. Ibid.

9. American Gas Association, "Supply." Accessed October 31, 2016. https://www.aga.org/supply.

10. EIA (U.S. Energy Information Administration), "Most of the Natural Gas Consumed in the United States is Produced Domestically." Accessed October 31, 2016.

https://www.eia.gov/energyexplained/index.cfm?page=natural_gas_where.

11. Gladstein, Neandross and Associates, Figure 25, "Comparative NOx and PM test levels for recently certified heavy-duty engines," in "Next Generation Heavy-duty Natural Gas Engines Fueled by Renewable Natural Gas," Game Changer Technical White Paper. Accessed December 12, 2016. http://ngvgamechanger.com/pdfs/GameChanger_FullReport.pdf.

12. California Air Resources Board (CARB), "CA-GREET 2.0 Model”. Accessed March 2017. https://www.arb.ca.gov/fuels/lcfs/ca-greet/ca-greet.htm.

13. EPA (U.S. Environmental Protection Agency), Table ES-2, "Recent Trends in U.S. Greenhouse Gas Emissions and Sinks," in Inventory of U.S. Greenhouse Gas Emissions and Sinks: 1990-2014, Washington D.C.: U.S. EPA (2016). Accessed October 31, 2016. https://www3.epa.gov/climatechange/Downloads/ghgemissions/US-GHG-Inventory-2016Main-Text.pdf. 
14. California Air Resources Board (CARB), "CA-GREET 1.8b vs. 2.0 CI Comparison Table," p. 10. Accessed October 31, 2016.

http://www.arb.ca.gov/fuels/lcfs/lcfs_meetings/040115_pathway_ci_comparison.pdf.

15. CARB, "Carbon Intensities (CIs) and Other Information from Registered Biofuel Facilities;" "Facilities with Approved Physical Pathways." Accessed March 2017. https://www.arb.ca.gov/fuels/lcfs/reportingtool/registeredfacilityinfo.htm; and https://www.arb.ca.gov/fuels/lcfs/reportingtool/registeredfacilityinfo.htm.

16. ICCT (International Council on Clean Transportation), "A Conversational Guide to ... Renewable Identification Numbers (RINs) in the U.S. Renewable Fuel Standard," p. 5, May 2014. Accessed 10/3/2106.

http://www.theicct.org/sites/default/files/publications/ICCTbriefing_RINs_20140508.pdf. "The number of RINs awarded for a given volume of a biofuel is based on [its] energy content [relative to ethanol]. One gallon of ethanol generates one RIN, but since biodiesel is more "energy dense"... it is awarded extra RINs. The equivalence value (EV) [emphasis added] is the approximate ratio of the energy density of the produced fuel to [that of] ethanol."

17. Alternative Fuels Data Center, U.S. DOE, "Fuel Properties Comparison,” October 2014. Accessed October 3, 2016. http://www.afdc.energy.gov/fuels/fuel_comparison_chart.pdf. According to the Center, one gallon of E100 ethanol has an energy value of roughly 76,000 Btus.

18. DOE (U.S. Department of Energy), "Renewable Natural Gas and RINs (Text Version)," transcript of a webinar presentation, June 2015. Accessed November 18, 2016. https://cleancities.energy.gov/webinars/59.

19. Office of the Governor, State of California, Exec. Order No. S-01-07 (January 18, 2007). Accessed November 22, 2016. https://www.arb.ca.gov/fuels/lcfs/eos0107.pdf.

20. CARB, “Low Carbon Fuel Standard-What is LCFS?” Accessed November 22, 2016. https://www.arb.ca.gov/fuels/lcfs/lcfs.htm.

21. California Energy Commission, "Projects: Clean World Partners Grant for Pre-Development Activities for a Biomethane Production Facility," CA.gov. Accessed November 1, 2016. http://www.energy.ca.gov/drive/projects/ARV-10-026.html.

22. Jim McKinney, "Alternative and Renewable Fuel and Vehicle Technology Program Update: Biogas focus," California Energy Commission presentation at the BioEnergy Association of California meeting, September 23, 2014. Accessed November 1, 2016.

http://www.bioenergyca.org/resources/presentations/cec-presentation-on-biofuels-funding/.

23. California Assembly Bill 1826 (AB-1826), “Organic Products.” (2015-2016). Accessed October 20, 2016 at: www.calrecycle.ca.gov/Recycle/Commercial/Organics

24. Michael Jarred, consultant, California State Assembly Committee on Natural Resources, personal communication, November 22, 2016. "Local jurisdiction" can also extend to "regional agencies," e.g., shared service arrangements between neighboring counties. 
25. CalRecycle, "Mandatory Commercial Organics Recycling (MORe)," CA.gov. Accessed November 2016. http://www.calrecycle.ca.gov/recycle/commercial/organics/.

26. Thi Dao, "Sacramento to Fuel Refuse Vehicles with Renewable Natural Gas," Government Fleet, July 15, 2013. Accessed November 1, 2016. http://www.governmentfleet.com/channel/green-fleet/news/story/2013/07/sacramento-to-fuel-refuse-vehicles-withrenewable-natural-gas.aspx?prestitial $=1$.

27. California Energy Commission (CEC), "California Clean Energy Tour - CleanWorld Sacramento BioDigester," CA.gov. Accessed October 2016. http://www.energy.ca.gov/tour/cleanworld/.

28. Tiangco, unpublished report and personal communication.

29. Katie Chapman, CleanWorld, personal communication, July 31, 2015.

30. Ibid.

31. Nora Goldstein, "Sacramento Food Waste Digester Fuels Collection Fleet," BioCycle, July 2013. Accessed November 2016. https://www.biocycle.net/2013/07/18/sacramentofood-waste-digester-fuels-collection-fleet/.

32. Ibid.

33. Moen, personal communication.

34. Energy Vision, New York, New York: 2017. http://energy-vision.org/.

35. Anna Simet, "California RNG Bill Could Open Door to Pipeline Injection.” Biomass Magazine, May 18, 2016. Accessed November 2016.

http://biomassmagazine.com/articles/13281/california-rng-bill-could-open-door-to-pipelineinjection.

36. Tiangco, unpublished report and personal communication.

37. CEC, "California Clean Energy Tour."

38. Atlas Disposal Industries, "Proposal."

39. Atlas Disposal Industries, "Proposal." From Section 3.5.2, “Anaerobic Digester," "...relatively little...energy" and "commercially available components."

40. CleanWorld, "CleanWorld Closes the Loop on Organic Waste," Cleanworld.com. Accessed January 4, 2017. http://www.cleanworld.com/technologies/products/.“...relatively little space, water."

41. CleanWorld, “Anaerobic Phased Solids Digester System," Cleanworld.com. Accessed November 28, 2016. http://www.cleanworld.com/technologies/products/aps-anaerobicphased-solids-digester-system/; Atlas Disposal Industries, "Proposal."

42. Atlas Disposal Industries, "Proposal." 
43. Wikipedia contributors, "Acidogenesis," Wikipedia, The Free Encyclopedia. Accesssed November 28, 2016. https://en.wikipedia.org/wiki/Acidogenesis.

44. University of California, Davis, and Onsite Power Systems, "Anaerobic Phased Solids Digester Pilot Demonstration Project," California Energy Commission, March 2011. Accessed November 28, 2016. http://www.energy.ca.gov/2013publications/CEC-500-2013077/CEC-500-2013-077.pdf.

45. Moen, personal communication.

46. Goldstein, "Sacramento Food Waste Digester Fuels."

47. “Synergex Ventures,” Synergex.com. Accessed October 27, 2016. http://www.synergex.com/synergex-ventures.

48. Goldstein, "Sacramento Food Waste Digester Fuels."

49. Otto Construction, "Clean World Partners (ARP \& SATS)." Ottoconstruction.com. Accessed November 2016. http://ottoconstruction.com/ portfolio-items/clean-world-partnersanaerobic-digester-sacramento-area-transfer-station-sats/.

50. CEC, "California Clean Energy Tour."

51. Chad Venderveen, "From Farm to Fork to Fuel," govtech.com, January 24, 2014. Accessed November 2016. http://www.govtech.com/fs/news/From-Farm-to-Fork-to-Fuel.html.

52. Tim Taylor, personal communication, December 5, 2016. "Emphasis on Compost," Sacramento Metropolitan Air Quality Management District and Sacramento Clean Cities Coalition.

53. Ibid.

54. Ibid.

55. CEC, "Notice of Proposed Award, Round 1, Alternative and Renewable Fuel and Vehicle Technology Program, Grant Solicitation PON-11-601.” Accessed November 23, 2016. http://www.energy.ca.gov/contracts/PON-11-601_NOPA.pdf.

56. CleanWorld News, "CleanWorld Expanding Successful Sacramento BioDigester," June 24, 2013. Accessed November 2016. http://www.cleanworld.com/news/cleanworld-expandingsuccessful-sacramento-biodigester/.

57. CEC, Notice of Proposed Award, Round 1, Alternative and Renewable Fuel and Vehicle Technology Program Grant Solicitation PON-11-602," April 24, 2012. Accessed November 23, 2016. http://www.energy.ca.gov/contracts/PON-11-602_NOPA.pdf. “\$300,000 coming from a CEC grant,"

58. Atlas Disposal Industries, "Proposal."

59. Atlas Disposal Industries, "Proposal,”; Energy Vision calculation. 
60. Tiangco, unpublished report and personal communication.

61. Energy Vision calculation. Assumes 50\% revenue in Year 1; Year 3 revenue 50\% greater than Year 2 during expansion; completion of 100 tpd capacity in Year 4 followed by operation at $60 \%$ capacity; $20 \%$ digestate sales; average $1.1 \%$ annual inflation on operating costs using "US Inflation Calculator,"

http://www.usinflationcalculator.com/inflation/current-inflation-rates/.

62. County of Sacramento, Municipal Services Agency, Department of Waste Management and Recycling, "Request for Proposal, Public Private Partnership for Energy Conversion Projects at Sacramento County's South Area Transfer Station," (Request for Proposal, May 18, 2011. Provided by Doug Kobold, Department of Waste Management and Recycling, County of Sacramento.)

63. Simet, "California RNG Bill Could Open Door."

64. Simet, "California RNG Bill Could Open Door," and California Legislative Information, bill status, “AB-2773 Biomethane.” Accessed November 2016.

http://leginfo.legislature.ca.gov/faces/billStatusClient.xhtml?bill_id=201520160AB2773. "technically infeasible."

65. Bill Quirk, member of California State Assembly, Legislative Office personal communication, December 5, 2017. “...allowed to die in committee...” Apparently, in addition to some opposition to loosening the siloxane requirement, the sponsors also decided they wanted to revise the Bill for future submission.

66. Moen, personal communication, December 2016.

67. EPA, "Part 80: EPA Fuel Programs Registered Company/Facility ID List (XLS)" from link Registered Companies and Facilities in Fuel Programs. Accessed November 26, 2016. https://www.epa.gov/fuels-registration-reporting-and-compliance-help/registered-companiesand-facilities-fuel-programs.

68. CARB, “LCFS Pathway Certified Carbon Intensities.” Accessed January 26, 2016. www.arb.ca.gov/fuels/lcfs/fuelpathways/pathwaytable.htm

69. Davis, S., S. Williams, and R. Boundy, Transportation Energy Data Book, Edition 35, Oak Ridge National Laboratory Report, ORNL-6992 (October 2016).

70. Michele Wong of Clean World at UC Davis Sustainable Transportation Energy Pathways (STEP) program workshop, "Critical Barriers and Opportunities to Accelerate Biofuels and Biomethane as Transportation Fuels in California," 2015 UC Davis Presentation. Accessed http://steps.ucdavis.edu/files/09/-17/-2015. Copy of archived presentation provided to Energy Vision by STEP program office, April 2017.

71. CleanWorld News, "CleanWorld Expanding Successful Sacramento BioDigester." http://www.cleanworld.com/news/cleanworld-expanding-successful-sacramento-biodigester/. 
72. CARB, "Low Carbon Fuel Standard Pathway for the Production of Biomethane from High Solids Anaerobic Digestion of Organic (Food and Green) Wastes." Accessed December 10, 2016 https://www.arb.ca.gov/fuels/lcfs/121514hsad.pdf.

73. Moen, personal communication, December 9, 2016.

74. CEC, "California Clean Energy Tour."

75. Tiangco, unpublished report and personal communication.

76. Ibid.

77. Mark Torresani, Cornerstone Environmental Group, personal communication, November 29, 2016; American Biogas Council. Accessed November 2016. https://www.americanbiogascouncil.org/.

78. Value for WWT sludge from Argonne National Laboratory; others based on data from Germany's Federal Ministry of Food, Agriculture and Consumer Protection (Bundesministerium für Verbraucherschutz, Ernährung, und Landwirtschaft, BMEL), 2005.

79. CEC, "California Clean Energy Tour."

80. CARB, "Low Carbon Fuel Standard Pathway for the Production of Biomethane from High Solids Anaerobic Digestion of Organic (Food and Green) Wastes." Accessed on January 10, 2017. https://www.arb.ca.gov/fuels/lcfs/121514hsad.pdf.

81. CARB, "LCFS Pathway Certified Carbon Intensities: Carbon Intensity Values of Current Certified Pathways (2016).” Accessed February 24, 2017. https://www.arb.ca.gov/fuels/lcfs/fuelpathways/pathwaytable.htm.

82. Atlas Disposal, "Proposal;" Tiangco, unpublished report and personal communication. Used as basis for all projections; additionally, digestate quantities were projected from $10 \mathrm{tpd}$, per "Proposal."

83. CEC, "California Clean Energy Tour." 



\section{Argonne}

\section{Energy Systems Division}

9700 South Cass Avenue, Bldg. 362

Argonne, IL 60439-4854

www.anl.gov 